\title{
POPULATION STRUCTURE AND THE HUMAN
} DEVELOPMENT INDEX*

\author{
Carmen Herrero ${ }^{\dagger}$ \\ Ricardo Martínez \\ Universidad de Alicante and IVIE Universidad de Granada \\ Antonio Villar ${ }^{\S}$ \\ Pablo de Olavide University and IVIE
}

January 30, 2018

\begin{abstract}
This paper provides an alternative way of measuring human development that takes explicitly into account the differences in the countries' population structures. The interest of this proposal stems from two complementary elements. First, that there is an enormous diversity in the population structures of those countries analysed in the Human Development
\end{abstract}

${ }^{*}$ The first author acknowledges financial support from project ECO2015-65820-P (MINECO/FEDER,UE) The second author also wishes to acknowledge financial support from Ministerio de Economía, under Project ECO2017-86245-P, as well as Junta de Andalucía un Project SEJ426. The third author acknowledges financial support from the Spanish MEC under project ECO2015-65408-R (MINECO/FEDER).

${ }^{\dagger}$ Departamento de Fundamentos del Análisis Económico. Universidad de Alicante. 03690 Alicante. Spain. Email: carmen.herrero@ua.es

${ }^{\ddagger}$ Departmento de Teoría e Historia Económica. Universidad de Granada. 03921 Granada. Spain. E-mail: ricardomartinez@ugr.es.

${ }^{\S}$ Corresponding author. Department of Economics, Universidad Pablo de Olvide, Ctra. Utrera km 1, 41013 Seville, Spain. E-mail:avillar@upo.es 
Reports, particularly the shares of old people in the population. Second, that demographic characteristics are relevant in the evaluation of development possibilities. We propose to change the way of measuring health, education and material wellbeing, in order to take into account those differences in the population structures. Regarding the health component, we substitute Life Expectancy at Birth by Life Potential (the average life expectancy of the current population); concerning education, we change the average between Mean Years of Schooling and Expected Years of Schooling by the Education Potential (a variable that mimics life potential in this context). As for the material well-being, we propose using the Gross National Income per adult, instead of per capita, while keeping logs in the evaluation. The resulting indicator, called Demographically Adjusted Human Development Index, is the geometric mean of the three new variables suitably normalised. We analyse empirically the effect induced by these changes in the evaluation of human development by comparing this way of measurement with the conventional Human Development Index (HDI) for 168 countries.

Keywords: Human development, health, education, income, life potential, education potential.

JEL Classification: O15, I31 


\section{Introduction}

The United Nations Human Development Index (HDI) is probably the most successful multidimensional welfare indicator elaborated so far. Its construction, following some of the ideas in Sen (1987), is relatively simple and intuitive. It starts by selecting three basic dimensions related to human development, health, education, and material wellbeing. Next, there is a choice of variables that associates empirical data to those dimensions. Finally, the measures of the three dimensions so obtained are aggregated as an average. Besides its ability to capture some of the basic traits of human welfare in an easily understandable way, the HDI has shown a relevant relationship with economic growth (e.g. Suri et al., (2011)).

There has been a vivid discussion on this construct, since its inception in 1990, debating all its features: the number and nature of the selected dimensions, the choice of the variables that approximate those dimensions, and the aggregation procedure. The original HDI was substantially reformulated in 2010 in response to the different critiques and alternative proposals that appeared in the literature. The main changes introduced referred to the way of measuring education, the substitution of the arithmetic mean by the geometric mean as the aggregator function, and the introduction of distributive considerations into the measurement. ${ }^{1}$ Needless to say, the new formulation is still subject to criticisms and new alternatives have been proposed (see Seth and Villar (2017a,b) and the references provided there). Fukuda-Parr et al., (2009), for instance, propose to include social rights proxies into de index. Lind (2004) defines the Time Allocation Index (TAI), which considers how people distribute their time on knowledge, long life, and wealth production. Bilbao-Ubillos (2013) proposes a measure that combines a wider variety of variables (such as poverty, gender situation, and personal safety) with a dynamic factor of

\footnotetext{
${ }^{1}$ There were also substantial changes in the design of some complementary measures, particularly regarding poverty.
} 
human development.

The aim of this paper is to enlarge that discussion by opening a way of introducing the demographic structure in the construction of the human development index. We understand that the design of an indicator of development, which is supposed to focus on capabilities rather than on realizations, should take into account the differences in the population structure. The reason is twofold. First, because the differences in the demographic structure among countries are huge, in particular regarding the shares of young and old people (see the examples in Figure 1 below). And second, because those differences have a bearing on the development capabilities as the population structure clearly affects the capacity of societies to keep or improve their living standards.

The United Nations has shown concern for the effects of demographic changes, in particular regarding population ageing: "Population ageing ... is poised to become one of the most significant social transformations of the twenty-first century, with implications for nearly all sectors of society, including labour and financial markets, the demand for goods and services, such as housing, transportation and social protection, as well as family structures and inter-generational ties." (United Nations (2015), p. 1). Yet, none of the variables selected to measure the three dimensions of human development, health, education and material wellbeing, take into account the demographic structure. Life expectancy at birth, which is the variable associated with health, is an expected value for the new born, independent on the shares of young and old people in the population. Education is approximated by the arithmetic mean of two different variables: the mean years of schooling (the number of years of education achieved by people aged 25 or more) and the expected years of schooling (the number of years of schooling that a child of school entrance age can expect to receive under the prevailing patterns of age-specific enrollment rates). There is no reference to the shares of people aged between 6 and 24, on the one hand, and 25 or 
more, on the other, which are relevant to determine the impact of changes in schooling. Finally, material wellbeing is associated with per capita Gross National Income (GNI), in logs, which is a variable that measures present achievements but again ignores the population structure (in particular the share of the working age population).

Our purpose here is to open a discussion on the need of introducing demographic considerations in the measurement of human development. We do so by proposing a variant of the HDI that takes into account the different population structures. This certainly requires introducing alternative ways of measuring the HDI components, even though we earnestly try to minimise the data requirements for the sake of feasibility. Regarding the health dimension we propose to use the variable life potential (Pinilla and Goerlich (2003)), which corresponds to the life expectancy of the present population (this is, the average number of life years remaining). Concerning education we shall introduce the notion of education potential, which can be regarded as an extension of the idea of life potential to this context. We shall show that this notion can be approximated by a weighted average of MYS and EYS with weights given by the corresponding population shares. Our way of approaching material wellbeing is in terms of the GNI per adult, in logs (see the discussion in Herrero et al., (2010), though). Using the adult population rather than the total one incorporates in an elementary way the differences in the population structure and has already become a standard reference in the analysis of wealth distribution (see Shorrocks et al., (2015)). Each of those three variables is normalized as the share of a reference value, in order to get partial indices between zero and one. ${ }^{2}$ Finally, the alternative human development index we propose, called Demographically Adjusted Human Development Index (DAHDI, hereafter), is the geometric mean of the three partial indicators.

The rest of the paper is organized as follows. In Section 2 we introduce and justify the new

\footnotetext{
${ }^{2}$ We depart here from the HDI normalization strategy because the use of max and min goalposts induces some inconsistencies in the aggregation process, as discussed in Herrero et al., (2012).
} 
variables we propose. We shall see that substituting life expectancy at birth by life potential is a major change of perspective, while the other changes have a smaller impact. In Section 3, we formally define the Demographically Adjusted Human Development Index we propose. Section 4 presents the main empirical findings and states the similarities and differences between our proposal and the current HDI. A few final comments are gathered in Section 5.

\section{The choice of variables}

We assume from the start that human development is associated with the three dimensions included in the HDI, health, education and material wellbeing. One may well argue that other dimensions are needed (e.g. sustainability), but this is not the subject of our discussion. We interpret, though, that human development capabilities are conditioned by the demographics so that any meaningful indicator should take into account this aspect. This approach leads to a choice of the variables associated with those three dimensions that differ from those present in the HDI. We devote this section to present and justify those alternative choices, with the selfimposed restriction of minimising the changes that require additional statistical information.

\subsection{Health: life potential.}

We propose here to change life expectancy at birth by life potential (LEB and LP, respectively, for short). Life potential refers to the average remaining life of a society and thus reflects the average of the life expectancy of the different generations, i.e. this variable discounts that part of the expected life already "used" (see Pinilla and Goerlich (2003)).

Let us present now the formal definition of life potential and then comment on its meaning and implications. For a given country $i$ and age $x \in \mathbb{Z}_{+}$, let $n_{i}^{x}$ denote the number of individuals in 
the society $i$ with age $x$, and let $n_{i}$ be the total population $\left(n_{i}=\sum_{x=0}^{\infty} n_{i}^{x}\right)$. If $e_{x}$ represents the expected numbers of years a person aged $x$ will still live, the life potential is given by:

$$
\mathrm{LP}=\frac{1}{n_{i}} \sum_{x=0}^{\infty} n_{i}^{x} e_{x}
$$

The formula makes it clear that life potential takes into account the demographic structure. In contrast, life expectancy at birth simply corresponds to $e_{0}$.

The choice of life potential, rather than life expectancy at birth, is motivated by a consistency requirement regarding the philosophical principles behind the HDI (i.e. focusing on capabilities). To see this note that life expectancy at birth is a variable constructed in such a way that it turns out to be independent on the demographic structure. ${ }^{3}$ As a consequence, it typically gives high scores in the health component to those countries with a higher share of old people. This last aspect is most arguable in the context of evaluating development capabilities because it ignores the differences in the working age population and, consequently, in the actual capacity of the labour force. Life potential, on the contrary, indicates the remaining years of life of a representative individual of the society, and therefore, takes into account both life expectancy and the demographic composition.

The difference between both concepts can be illustrated by the following analogy. We can think of life years as the matches in a matchbox. Life expectancy at birth tells us how many matches you get when receiving a new matchbox in a given country, while life potential tells us how many matches you would find in the matchbox held by an average citizen.

It is not difficult to foresee that this change of variable will typically penalise those developed countries with high values of life expectancy at birth but with a large proportion of old people. And vice-versa: countries with a wider base in their population pyramids will get a better score in this dimension. The final effect will clearly depend on the relative differences in life expectancy

\footnotetext{
${ }^{3}$ This is so for a reason: avoiding the composition effect that derives from the use of mortality rates.
} 
values and population structures by age. One would also expect to find high correlation between LEB and LP in countries with a similar population structure.

Figure 1 shows the population pyramids for six illustrative cases, whose life expectancy at birth is given in parentheses: Germany (80.9), Honduras (73.1), India (68), Japan (83.5), Nigeria (52.8), and United States (79.1). Comparing these data with the population structures in Figure 1 makes it clear that measuring life expectancy at birth or life potential is going to be very important regarding the picture we get from the relative situation of the different countries.

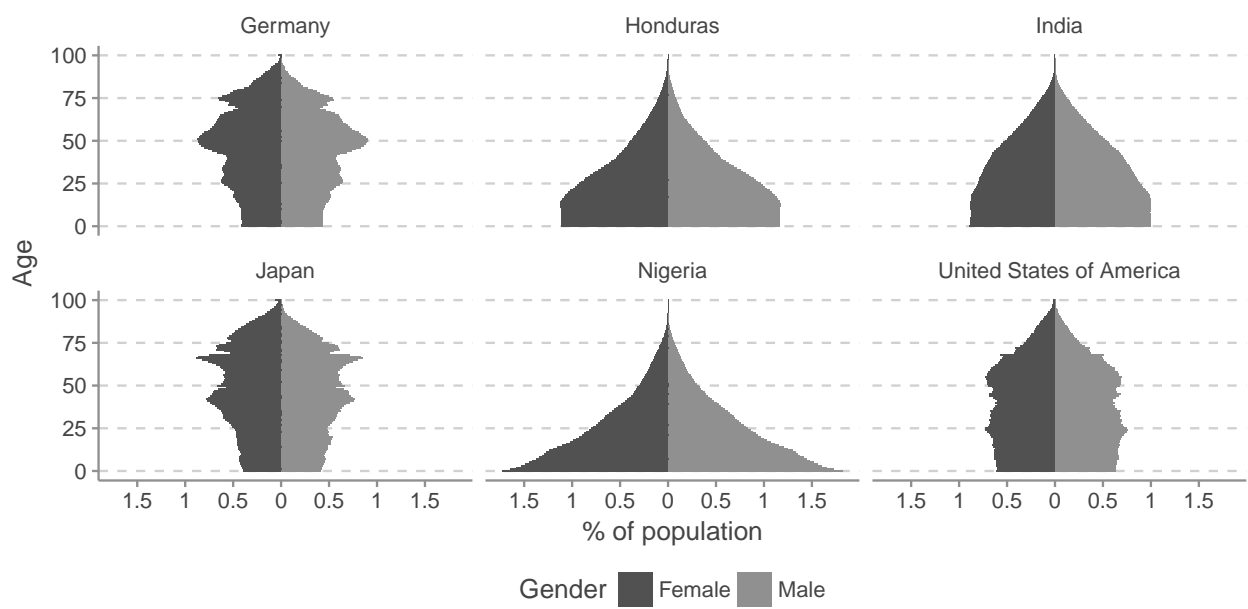

Figure 1: Population pyramids of several countries in 2015.

In order to calculate the life potential we combine the data from two sources. The World Health Organization provides the life expectancy for each gender and group of age. ${ }^{4}$ The US Census Bureau database contains the countries population by single year of age and gender. Following the definition above, we compute the life potential as the population-weighted sum of the life expectancy of the people within each age range. All data refer to year 2015. Table 1 shows the main statistics for both variables. ${ }^{5}$

\footnotetext{
${ }^{4}$ The groups are: $[0,1],[2,4],[5,9],[10,14], \ldots,[95,99],[100, \infty]$.

${ }^{5}$ For the LEB we have used the data provided by United Nations for 2015.
} 


\begin{tabular}{lrr}
\hline Statistic & LP & LEB \\
\hline Min & 37.4 & 49.0 \\
Median & 47.5 & 73.4 \\
Mean & 46.9 & 71.4 \\
Max. & 54.9 & 85.3 \\
Coeff. of Variat. & 0.08 & 0.11 \\
\hline
\end{tabular}

Table 1: Descriptive statistics for LP and LEB.

The coefficient of variation is higher in the LEB (0.11) than in the LP (0.08), that is, countries are slightly more heterogeneous with respect to the life expectancy at birth than with respect to the life potential. The relative range of values (maximum minus minimum over the mean) for LEB is also larger in LEB (0.51) than in LP (0.37). We complete the comparison by showing that LP and LEB are not correlated at all $(\rho=-0.05){ }^{6}$

\footnotetext{
${ }^{6}$ Even though the LP and the LEB are not correlated, when we restrict to particular areas like Europe we observe that both variables are related $(\rho=0.82)$.
} 


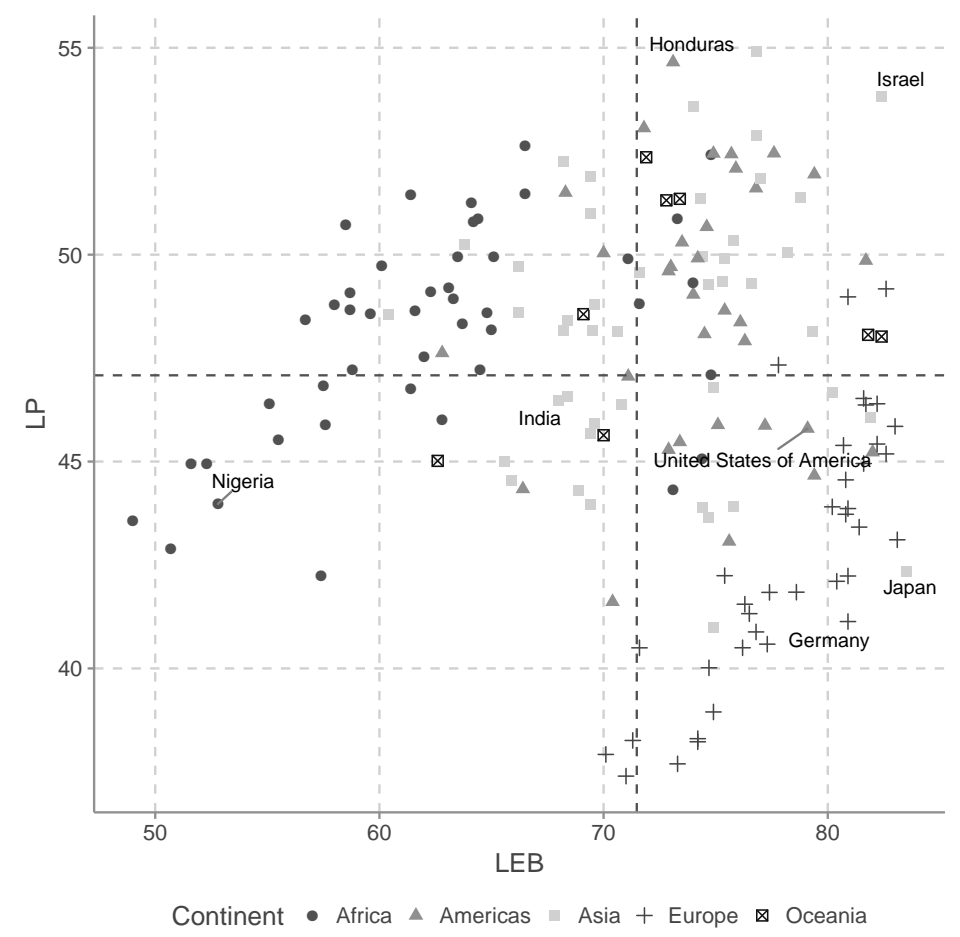

Figure 2: Correlation between LP and LEB.

In Figure 2 each dot represents a country, whose colour and shape depend on the continent to which the country belongs to. The LEB is on the horizontal axis and the life potential is on the vertical one. The dashed lines indicate the mean of each variable. As we can observe, most of the European countries have very high life expectancy at birth but rather low life potential. This is because they have aged populations and, in many cases, their demographic structure looks like Germany in Figure 1. The situation of Africa, for instance, is very different: almost all African countries are below the LEB mean, whereas most of them perform better than the world's LP average.

Table 5 details the results for all the countries in the dataset. Countries are sorted according to its life potential. The fourth and fifth columns refer to their position in the ranking for the life potential and life expectancy at birth, respectively. As we can observe, the differences are important. Some of the European countries that perform really well with respect to the 
life expectancy at birth go down more than 100 positions in the LP ranking. Japan (first in LEB) is in the 146th position for LP, the biggest jump. On the opposite side, many American countries perform much better in life potential than in life expectancy at birth. Honduras, Guatemala, or Panama occupy top positions in the ranking, together with other countries of the Arabian peninsula like Oman or Jordan. The case of Israel is special, it seems to get a good balance between life expectancy at birth and life potential, performing significantly well in both measures.

\subsection{Education: education potential.}

The HDI measures educational achievements as the simple average of the mean years of schooling (MYS) and the expected years of schooling (EYS). The MYS is the average number of years of education received by people aged 25 and older, converted from education attainment levels using official duration of each level. The EYS is the number of years of schooling that a child of school entrance age is expected to obtain under the prevailing patterns of age-specific enrolment rates. We have already mentioned that using the simple arithmetic mean between both components amounts to disregarding the population structure. Note that the impact on the development capabilities of this variable depends very much on the share of people between 6 and 25 in the whole population.

We can apply here a similar approach to that used for the health variable and define the education potential by analogy. This would require computing the educational achievements of the different cohorts of people above 25 and estimates of the expected years of schooling of those between 6 and 24. Getting the data to compute this value is going to be extremely difficult, if not impossible, for many countries. Yet we can get a reasonable approximation. For those above 25 we keep the MYS as a good proxy of their achievements in education, while for the population 
below 24 we use a weighted version of the EYS (called WEYS), which takes into account the population structure and the school life expectancies within each of the three education levels (primary, secondary, and tertiary).

We explain now the construction of the WEYS. For a given country $i$, let us consider the following variables: ${ }^{7}$

- $\mathrm{EAP}_{i}$ : Entrance age to primary education (age)

- $\mathrm{TDP}_{i}$ : Theoretical duration of primary education (number of years).

- $\operatorname{TDS}_{i}$ : Theoretical duration of secondary education (number of years).

- $\mathrm{SEP}_{i}$ : School life expectancy within primary education (number of years).

- $\mathrm{SES}_{i}$ : School life expectancy within secondary education (number of years).

- $\mathrm{SET}_{i}$ : School life expectancy within tertiary education (number of years).

- $\mathrm{ERP}_{i}$ : Enrollment in primary education (number of students).

- $\mathrm{ERS}_{i}$ : Enrollment in secondary education (number of students).

- $\mathrm{ERT}_{i}$ : Enrollment in tertiary education (number of students).

From these, we can obtain other variables required for the computation of the WEYS.

- $\mathrm{EAS}_{i}$ : Entrance age to secondary education

$$
\mathrm{EAS}_{i}=\mathrm{EAP}_{i}+\mathrm{TDP}_{i}
$$

\footnotetext{
${ }^{7}$ For the MYS we have used the data from the United Nations in 2015. The rest of the variables are obtained from the dataset the UNESCO Institute for Statistics provided by the World Bank, and, for each country, they refer to the last available data in the database. As in the case of health, the data on the population are obtained from the US Census Bureau.
} 
- $\mathrm{EAS}_{i}$ : Entrance age to tertiary education

$$
\mathrm{EAT}_{i}=\mathrm{EAS}_{i}+\mathrm{TDS}_{i}
$$

- $\mathrm{EYST}_{i}$ : Expected years of foreseen education of a person that starts the tertiary level.

$$
\mathrm{EYST}_{i}=\mathrm{SET}_{i}
$$

- $\mathrm{EYSS}_{i}$ : Expected years of foreseen education of a person that starts the secondary level.

$$
\mathrm{EYSS}_{i}=\mathrm{SES}_{i}+\frac{\mathrm{ERT}_{i}}{\mathrm{ERT}_{i}} \cdot \mathrm{SET}_{i}
$$

- $\mathrm{EYSP}_{i}$ : Expected years of foreseen education of a person that starts the primary level.

$$
\mathrm{EYSP}_{i}=\mathrm{SEP}_{i}+\frac{\mathrm{ERS}_{i}}{\mathrm{ERP}_{i}} \cdot \mathrm{SES}_{i}+\frac{\mathrm{ERS}_{i}}{\mathrm{ERP}_{i}} \cdot \frac{\mathrm{ERT}_{i}}{\mathrm{ERS}_{i}} \cdot \mathrm{SET}_{i}
$$

If $n_{i}^{[a, b]}$ denotes the population of country $i$ with ages between $a$ and $b$, the weighted expected years of schooling (WESY) is given by:

$$
\mathrm{WEYS}_{i}=\frac{1}{n_{i}^{\left[\mathrm{EAP}_{i}, 24\right]}}\left[n_{i}^{\left[\mathrm{EAP}_{i}, \mathrm{EAS}_{i}-1\right]} \cdot \mathrm{EYSP}_{i}+n_{i}^{\left[\mathrm{EAS}_{i}, \mathrm{EAT}_{i}-1\right]} \cdot \mathrm{EYSS}_{i}+n_{i}^{\left[\mathrm{EAT}_{i}, 24\right]} \cdot \mathrm{EYST}_{i}\right]
$$

To sum up, the WEYS is a proxy of the years of education an individual that ages between the school entrance age and 24 expects to get.

Following the same reasoning as in the previous section, we define the education potential as the weighted average of the educational achievements of people above 25 (the MYS) and the expectancy of those below 25 (the WEYS). The weights are given by the corresponding population shares. This construct provides a much better measure of the impact of the changes in educational achievements as it implicitly incorporates a reference to the velocity with which those changes are going to spread. The formal expression of the education potential is:

$$
\mathrm{EP}_{i}=\frac{1}{n_{i}^{\left[\mathrm{EAP}_{i},+\infty\right]}}\left[n_{i}^{\left[\mathrm{EAP}_{i}, 24\right]} \cdot \mathrm{WEYS}_{i}+n_{i}^{[25,+\infty]} \cdot \mathrm{MYS}_{i}\right]
$$


In order to make a proper comparison between our proposal and the variables used by the United Nations, we construct the corresponding partial indices. Notice that we need those partial indices because, unlike the case of health, in the HDR the education component consists of two parts (MYS and EYS).

$$
\mathrm{EI}_{\mathrm{UN}}=\frac{1}{2}\left[\frac{\mathrm{MYS}}{15}+\frac{\mathrm{EYS}}{18}\right]
$$

and

$$
\mathrm{EI}=\frac{\mathrm{EP}}{13}
$$

For the normalization of the MYS and EYS we keep the upper bounds of Jahan (2015), while for the EP we use 13. Table 2 shows the main statistics for both variables.

\begin{tabular}{lrrr}
\hline Statistic & EYS & MYS & EP \\
\hline Min & 4.1 & 1.4 & 1.8 \\
Median & 13.3 & 8.5 & 7.5 \\
Mean & 13.0 & 8.2 & 7.2 \\
Max. & 20.2 & 13.1 & 12.3 \\
Coeff. of Variat. & 0.21 & 0.37 & 0.37 \\
\hline
\end{tabular}

Table 2: Descriptive statistics for EYS, MYS, and EP.

As we did for the health component, Figure 3 illustrates the relationship between $\mathrm{EI}_{\mathrm{UN}}$ and EI. Each dot represents a country, whose colour and shape depend on the continent to which the country belongs. The $\mathrm{EI}_{\mathrm{UN}}$ is on the horizontal axis and the EI is on the vertical one. The dashed lines indicate the mean of each variable. Unlike the case of health, the two ways of measuring the education component exhibit a very high correlation $(\rho=0.97)$. Hence, European 
countries perform well in both indicators (they are above the average), while the achievements of Africa are poor for any of the measures (below the average in both cases).

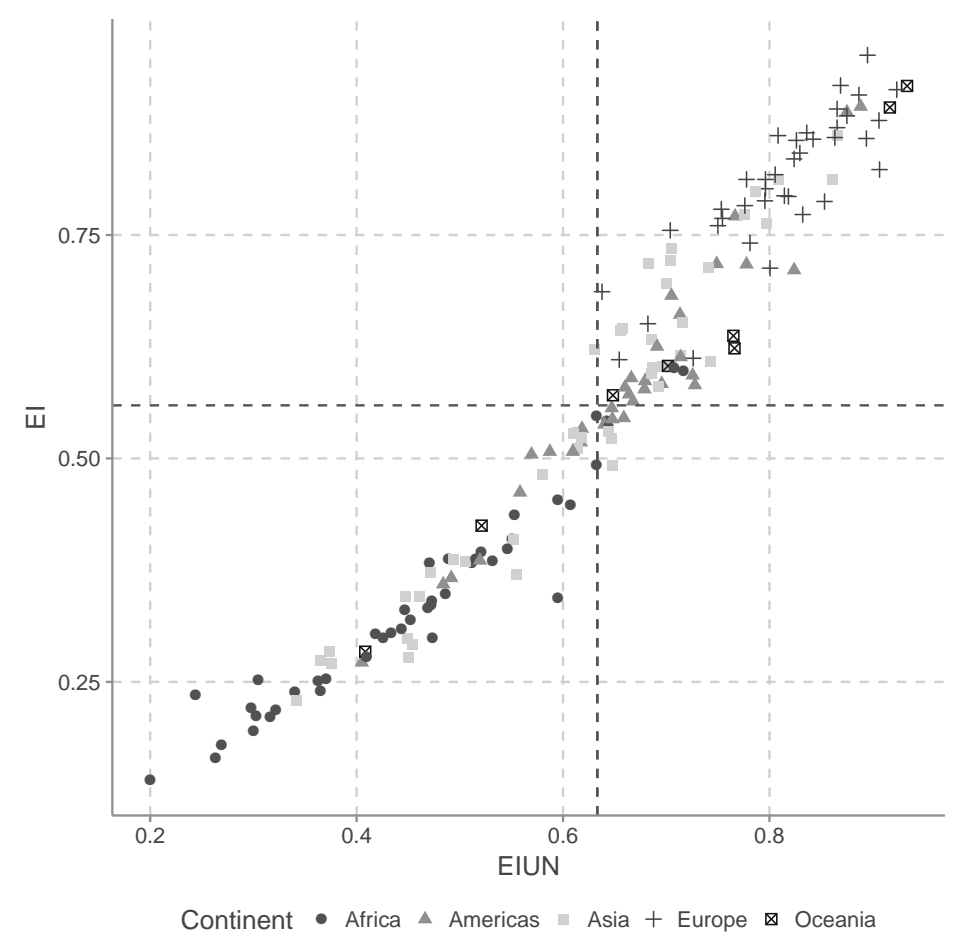

Figure 3: Correlation between EI and $\mathrm{EI}_{\mathrm{UN}}$.

Table 6 lists all the countries, ordered according to the education indicator EI. The first column refers to the country. The second, third, and fourth columns refer to the EP, EYS, and MYS, respectively. Columns sixth and seventh are for the $\mathrm{EP}$ and $\mathrm{EI}_{\mathrm{UN}}$. Columns eighth and ninth refer to the position in the raking according to $\mathrm{EP}$ and $\mathrm{EI}_{\mathrm{UN}}$, while the last column is the difference between those positions. The changes are not as relevant as in the case of health. Countries both at the very top and at the very bottom do not exhibit big jumps, thus, in general, if they perform well or bad for one indicator they also do it for the other. But still, from a conceptual point of view, the EP is more consistent with the interpretation of the human development index as a measure of the current welfare of a society by means of the achievements of a presentative individual. 


\subsection{Income: GNI per adult}

Our proposal regarding the variable to approach material wellbeing is taking the Gross National Income per adult, rather than per capita. This is a relatively simple way of incorporating the demographic structure when the information on the size and composition of households is not available for all countries. This approach has been successfully applied to the analysis of wealth distribution (see Shorrocks et al., (2015)).

Making income or wealth comparisons between countries with different population sizes and structures puts always the question of how to choose the appropriate units of analysis. There is some consensus on the use households adjusted by size and composition by recurring to some equivalence scale (see Harttgen and Klasen (2012) for an application to the HDI). When information on households is not available, or membership cannot be clearly ascertained, or household structures are very different, one may consider preferable refer the analysis to the individuals, rather than to the households. The most common option is taking per capita values. Using the adult population, instead of the whole population, seems preferable to us for two main reasons. First, because it permits taking into account in a very simple way the demographic differences. And second, because the command over the family resources is typically in the hands of the adults and the children have little decision power. 


\begin{tabular}{lrr}
\hline Statistic & GNIpa & GNIpc \\
\hline Min & 1095 & 581 \\
Median & 15920 & 10980 \\
Mean & 22840 & 16820 \\
Max. & 144200 & 123100 \\
Coeff. of Variat. & 0.98 & 1.06 \\
\hline
\end{tabular}

Table 3: Descriptive statistics for GNI per adult and per capita.

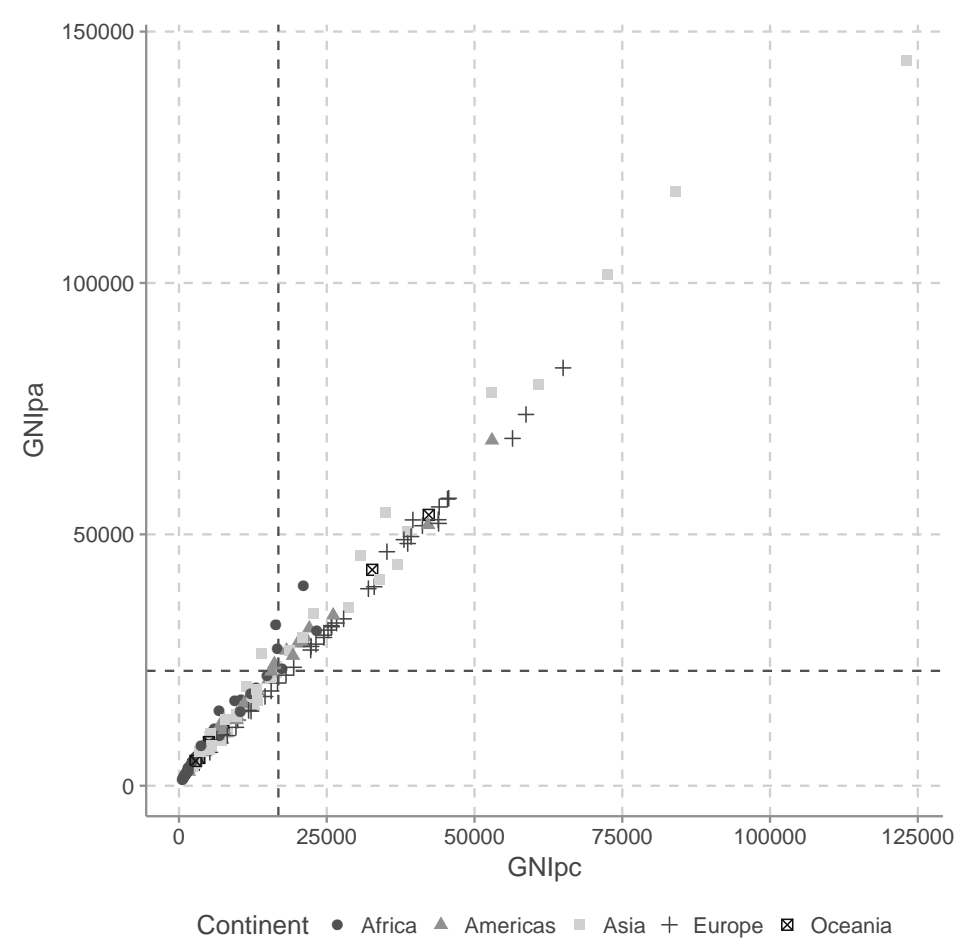

Figure 4: Correlation between the GNI per adult and per capita.

There are not important changes in the ordering of countries when we substitute the GNI per capita by the GNI per adult, and the big jumps are scarce. This is far from unexpected, due to the large dispersion of those values. The details on these variables and their rankings are in Table 7. 


\section{The alternative human development index.}

In the previous section we have introduced the variables we propose to measure the achievements in each of the three dimensions that the HDI considers. Regarding health, we propose using life potential rather than life expectancy at birth. With respect to education, we consider using the education potential, rather than the arithmetic mean between the EYS and the MYS. Finally, we opt to approach material wellbeing in terms of GNI per adult, without logs, rather than GNI per capita. Let us now present the closed formula of the Demographically Adjusted Human Development Index, DAHDI.

$$
\text { DAHDI }=\left[\frac{\mathrm{LP}}{56} \cdot \frac{\mathrm{EP}}{13} \cdot \frac{\log (\text { GNIpa })}{\log (85000)}\right]^{\frac{1}{3}}
$$

in contrast with the human development index used by United Nations

$$
\mathrm{HDI}=\left[\frac{\mathrm{LEB}-20}{85-20} \cdot \frac{1}{2}\left(\frac{\mathrm{EYS}}{18}+\frac{\mathrm{MYS}}{15}\right) \cdot \frac{\log (\mathrm{GNIpc})-\log (100)}{\log (75000)-\log (100)}\right]^{\frac{1}{3}} .
$$

There are two aspects worth mentioning when comparing the DAHDI and the conventional HDI. First, that both measures share the same aggregation formula (a geometric mean). The advantage of the geometric mean vis a vis the arithmetic mean is already well established (see for instance Herrero et al., (2010)). So, our proposal does not differ in this respect from the current HDI. Second, that both formulae differ in their normalization strategies. As shown in Herrero et al., (2012), the normalization applied in the HDI to health and income leads to significant drawbacks, mostly due to the use of lower bounds that may artificially alter the raking of the countries. We only use, therefore, the max values to normalize each variable. 


\begin{tabular}{lcc}
\hline Statistic & HDI & DAHDI \\
\hline Min & 0.34 & 0.44 \\
Median & 0.72 & 0.75 \\
Mean & 0.69 & 0.72 \\
Max. & 0.94 & 0.91 \\
Coeff. of Variat. & 0.21 & 0.15 \\
\hline
\end{tabular}

Table 4: Descriptive statistics HDI and DAHDI.

The numerical results and comparisons are detailed in Table 8, where the first column is the country, the columns two, three, and four are for the partial indices of health $\left(\mathrm{HI}=\frac{\mathrm{LP}}{56}\right)$, education $\left(\mathrm{EI}=\frac{\mathrm{EP}}{13}\right)$, and income $\left(\mathrm{YI}=\frac{\mathrm{GNIpa}}{85000}\right)$, respectively. The fifth and the sixth columns correspond to the DAHDI and the HDI. Finally, columns seven, eight, and nine describe the position of the country according to the DAHDI, the HDI, and the changes in the ranking.

Our first finding is that the DAHDI and the HDI are ordinaly different. Beyond the mere observation of the changes in the orderings in Table 8, both the Kendall's $\tau$-test and the Spearman's $\rho$-test (with p-values smaller than $2.2 \cdot 10^{-16}$ in both cases) indicate that the introduction of the population structure in the human development index has a significant impact on the countries ranking. Note that there are countries such as Norway, Switzerland, USA, or Australia that perform quite well in both indices. Yet, there are other countries whose population structures impact more deeply in their human development. This is the case of Spain, Italy, and Greece (all of them in the south of Europe with many socio-economic similarities) that go down in the ranking more than 12 positions. Portugal is an extreme case, since it losses 39 positions, the biggest jump down. 
Figure 5 presents the distribution of the DAHID and the HDI, normalizing to one the highest value achieved by a country with each index. Note that here the same point in the horizontal axis may correspond to different countries, depending on the chosen index. The graphic shows a different picture of the distribution of the development levels, depending on the indicator. We observe that the relative level of human development of the most developed countries does not change very much from one to other indicator. Those countries with medium or low level of development, though, exhibit relevant differences. Also note that the DAHDI shrinks the distribution, with the result that the least developed country represents $47.6 \%$ of the most developed one, whereas in the case of the HDI this figure is a $36.8 \%$.

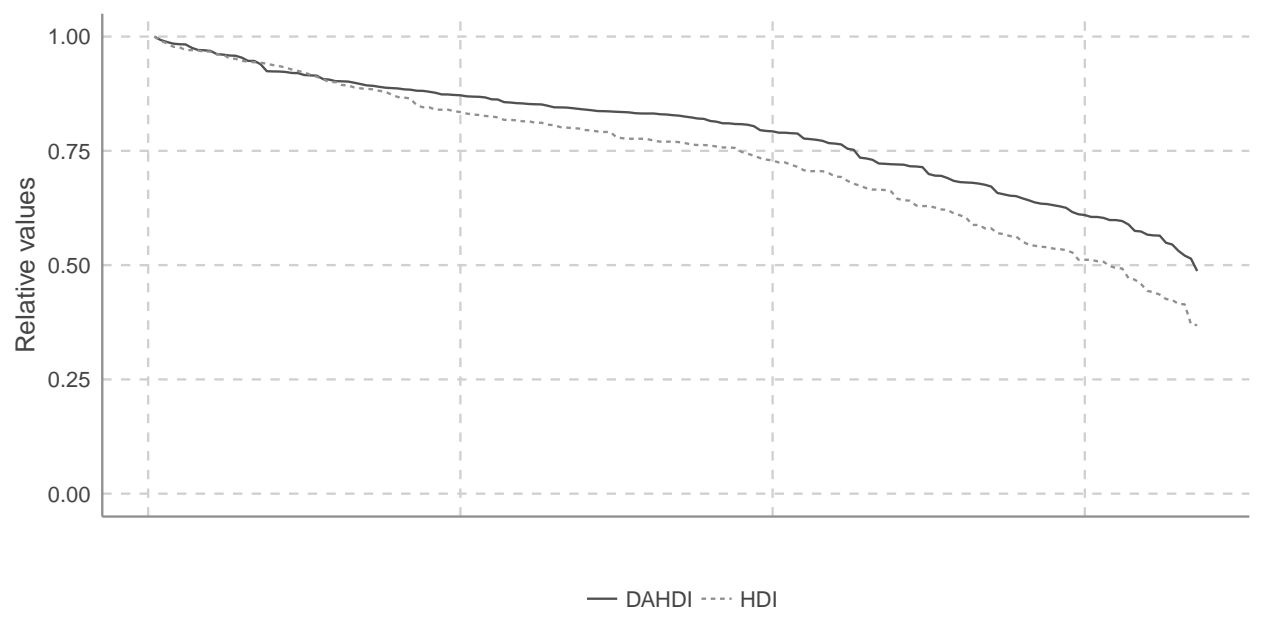

Figure 5: Relative distributions of the DAHDI and the HDI.

We plot in Figure 6 the cumulative distribution of both indices. We observe that the left and right tails are shorter for the HDI than for the DAHDI, which indicates that: (a) There are more countries with a poor performance in the HDI than in the DAHDI (absolute zeros excluded); and (b) Less countries achieve the highest level of human development with the HDI than with the DAHDI. This figure also illustrates that the distribution of values is more even (almost constant marginal increments) in the case of the standard HDI. 


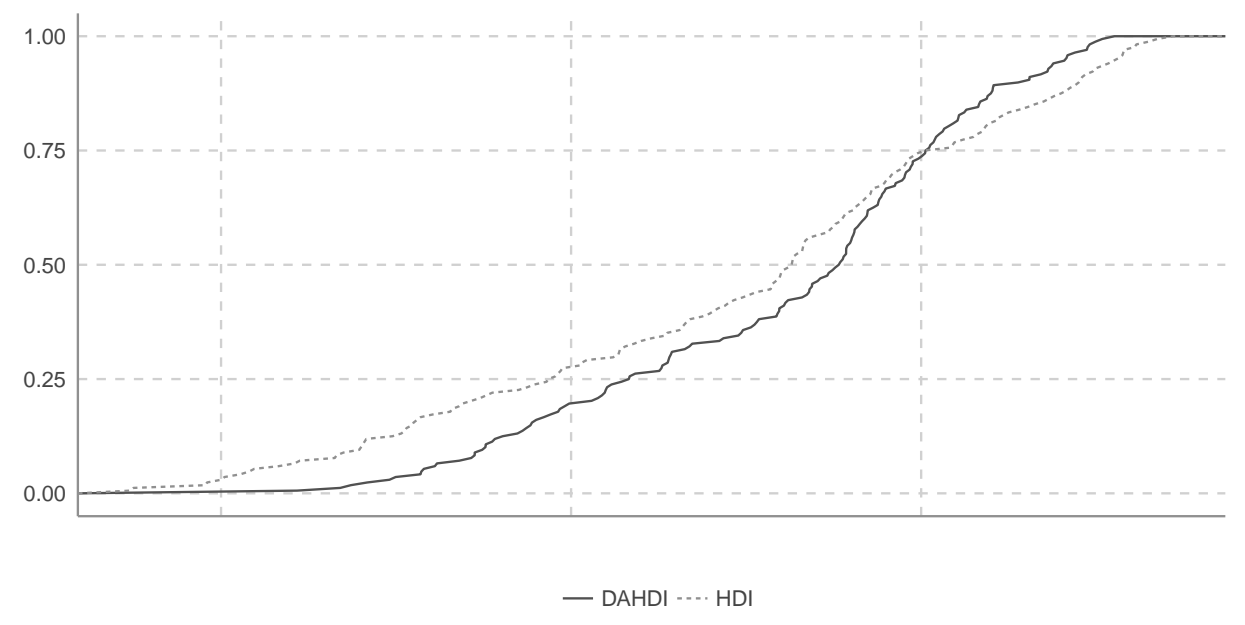

Figure 6: Cumulative distributions of the DAHDI and the HDI.

\subsection{Cluster analysis}

We complete our study by classifying the countries into four different categories according to their level of human development, as the United Nations does. Yet, we follow Abad-González and Martínez (2016) and apply clustering techniques to this task, not imposing any a priory grouping (the Human Development Reports consider an exogenous classification). Generally speaking, clustering methods are based on identifying a partition of observations such that observations within each cluster or group are as similar as possible and observations between different clusters or groups are as dissimilar as possible. We use a hierarchical method, in particular we apply the Ward algorithm discussed by Kaufman and Rousseeuw (1990) and Legendre and Legendre (2012). This method collapses, at each stage, the two clusters whose union minimizes the distance to any other third cluster. The results are in Tables 9 (for DAHDI) and 10 (for HDI) below.

We observe that the set of high human development countries is much larger for the DAHDI than for the HDI. We also find that there are fewer hight and medium development countries 
according to the DAHDI. The low tail of the distribution does not exhibit significant changes. Not surprisingly, some countries change of group. Portugal, for instance, moves from high development in HDI to medium development in DAHDI. Other countries, such as Turkey or Cameroon, upgrade their category.

\section{Final remarks}

We have presented in this paper the demographically adjusted human development index (DAHDI). This new measure stems from the basic consideration that a welfare index that follows the capability approach should take into account the population structures, as it aims at capturing not only achievements but also possibilities. A summary inspection of the data shows that there are countries with similar achievements but with rather different balance of young and old people in their populations, thus confronting very different paths to keeping or improving welfare.

Our proposal is decidedly a very conservative one. Indeed, we suggest very minor changes to the current HDI. We keep the three key dimensions of human development (health, education and material well-being) and we also maintain the aggregation formula (the geometric mean of the partial indices). The new variables we choose to approximate each dimension are very close

to the conventional ones. Regarding the health component, we move from life expectancy at birth (LEB) to life potential (LP). For education we change the average between mean years of schooling (MYS) and expected years of schooling (EYS) by the education ootential (EP). As for the material well-being variable, we simply substitute the GNI per capita for the GNI per adult, keeping logs in the evaluation. Finally, we slightly changed the normalization strategy to avoid some possible inconsistencies. This strategy reduces the informational cost of implementing this new indicator and makes it easier to compare it with the conventional HDI. 
Needless to say, this is not the only way of introducing the demographic structure in the measurement of human development. Yet this is a consistent approach of doing it and it is to be interpreted as an initial platform to open the discussion on the role of the demographic differences in the evaluation. The empirical analysis presented shows clearly that even those relatively minor changes induce substantial alterations of the overall index. Demographers tend to consider three different population structures, in terms of the shape of the corresponding population pyramids. The first one is the expansive type, which corresponds to societies with larger shares of young people in the population. This type of age-sex distribution takes the form of a true pyramid and is usually found in countries with very large fertility rates and lower than average values or life expectancy at birth. The age-sex distributions of many less developed countries display expansive population pyramids. The second one is the constrictive type, characterized by low shares of young people in the population and results in a sort of rhomboidal distribution. European countries, such as Greece, Italy, Portugal, Spain or Switzerland fall into this type of pyramid. The last type is that of a stationary or near-stationary population pyramid, that present a rectangular shape (even though there are always smaller figures for the oldest age groups). The age-sex distributions of some European countries, especially Scandinavian ones, as well as the United States, fall into this category.

The effect of different types of population pyramids on the variables chosen is quite apparent. Take the case of the comparison between LEB and LP. We find countries with similar LEB but different types of pyramids that yield very different LP. A case in point is that of Israel (with an expansive pyramid) and Australia (with a near-stationary pyramid); both have the same LEB, 82.4, but they have very different LP (53.8 and 48.0, respectively). Regarding the LEB they are both in position 6 in the ranking, while regarding LP they occupy positions 3 and 83, respectively. Japan, with a constrictive pyramid, has a LEB of 83.5 years and a LP of 42.3, dropping from the first position in terms of LEB to position 146 in terms of LP. As for 
the income component, we may consider Azerbaijan (with a near-stationary pyramid), Belarus (with a constrictive one), and Gabon (with an expansive pyramid). They have a GNI per capita of 16676, 16428, and 16367, respectively, occupying positions 57, 60 and 61. Their GNI per adult are $22470.90,20426.92$, and 31948.94 , that puts them at the 63,68 , and 37 positions, respectively.

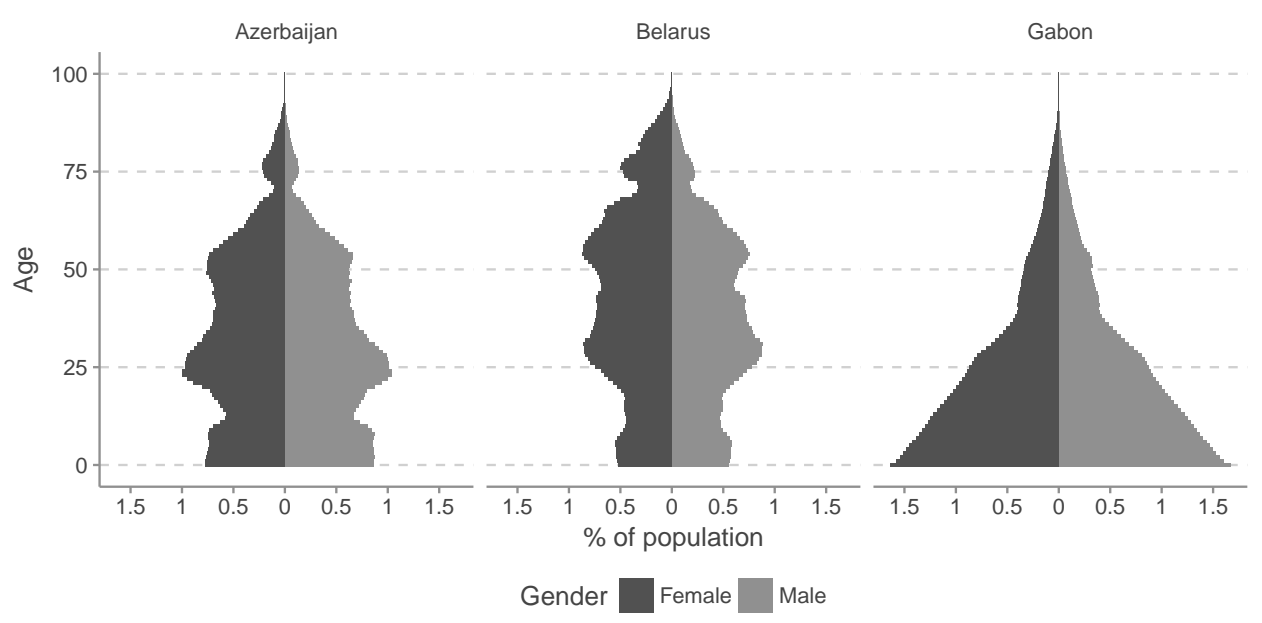

Figure 7: Population pyramids of several countries in 2015.

We find that countries with expansive population pyramids do better in terms of LP than in terms of LEB, and obtain better scores with the new way of measuring human development. The contrary happens for those countries with constrictive population pyramids (something that can also be observed, with less intensity, for countries with near-stationary pyramids). The introduction of the population structure in the education variable has little effect (EP is highly correlated with EI), but its introduction has been made for consistency reasons (see Lutz and KC (2013) for a discussion).

Let us point out that this approach to human development helps paying attention to the consequences of an aging population. This does not mean that we consider that countries with older populations have less chances of economic progress or that countries with high fertility rates 
are better positioned. ${ }^{8}$ Yet the shares of young and old people in the population are relevant variables for a sustainable development. Ignoring the existing differences in those variables provides a distorted view of human development, making some developed countries look artificially better.

Also note that this approach induces a positive view of immigration in those countries with constrictive population pyramids as it typically improves the share of young people in the population and the size of the labor force. Immigration may translate into positive effects for the recipient countries, both regarding LP and GNI per adult.

\footnotetext{
${ }^{8}$ Population ageing is an important phenomenon with many implications to be taken into account, but this does not mean that there is a negative relationship between ageing and economic growth (see Bloom et al., (2010), Maestas et al., (2016), Acemoglu and Restrepo (2017)).
} 


\section{References}

Abad-González, J. and Martínez, R. (2016). Endogenous categorization of the human development. Applied Economics Letters, 24:243-246.

Acemoglu, D. and Restrepo, P. (2017). Secular stagnation? The effect of aging on economic growth in the age of automation. NBER Working Papers, 23077.

Bilbao-Ubillos, J. (2013). Another Approach to Measuring Human Development: The Composite Dynamic Human Development Index. Social Indicators Research, 111:473-484.

Bloom, D. E., Canning, D., and Fink, G. (2010). Implications of population ageing for economic growth. Oxford Review of Economic Policy, 26:583-612.

Fukuda-Parr S., Lawson-Remer, T., and Randolph, S. (2009). An Index of Economic and Social Rights Fulfillment: Concept and Methodology. Journal of Human Rights, 8:195-221.

Harttgen, K. and Klasen, S. (2012). A household-based human development index. World Development, 40:878-899.

Herrero, C., Martínez, R., and Villar, A. (2010). Multidimensional social evaluation: An application to the measurement of human development. Review of Income and Wealth, 56:483-497. (2012). A newer human development index. Journal of Human Development and Capabilities, $13: 247-268$.

Jahan, S. (2015). Human Development Report 2015. United Nations.

Kaufman, L. and Rousseeuw, P. (1990). Finding Groups in Data: An Introduction to Cluster Analysis. Wiley

Legendre, P. and Legendre, L. (2012). Numerical Ecology. Elsevier. 
Lind, N. (2010). Values Reflected in the Human Development Index. Social Indicators Research, 66:283-293.

Lutz, W. and KC, S. (2013). Demography and human development: Education and population projections. Occasional Paper UNDP Human Development Report Office, 4.

Maestas, N., Mullen, K., and Powell, D. (2016). The effect of population aging on economic growth, the labor force and productivity. NBER Working Papers, 22452.

Pinilla, R. and Goerlich, F. (2003). Renta per cápita y potencial de calidad de vida (QLP) en España (1981-1999). Working Paper IVIE, 2.

Sen, A. (1987). Commodities and Capabilities. Oxford University Press.

Seth, S. and Villar, A. (2017a). Human development, inequality and poverty: Empirical findings. In C. D'Ambrosio, editor, Handbook of Research on Economic and Social Wellbeing. Edward Elgar.

(2017b). The measurement of human development and poverty. In C. D'Ambrosio, editor, Handbook of Research on Economic and Social Wellbeing. Edward Elgar.

Shorrocks, A., Davies, J., and Lluberas, R. (2015). Global wealth report 2015. Crédite Suisse, Zurich.

Suri, T., Boozer, M. A., Ranis, G., and Stewart, F. (2011). Paths to success: The relationship between human development and economic growth. World Development, 39:506-522.

United Nations (2015). World Population Ageing 2015. UN Department of Economic and Social Affairs, Population Division. 
Appendix A. Tables.

\begin{tabular}{|c|c|c|c|c|c|}
\hline Country & LP & LEB & $\operatorname{Rank}_{\mathrm{LP}}$ & $\operatorname{Rank}_{\mathrm{LEB}}$ & Diff. rankings \\
\hline Oman & 54.9 & 76.8 & 1 & 44 & 43 \\
\hline Honduras & 54.7 & 73.1 & 2 & 90 & 88 \\
\hline Israel & 53.8 & 82.4 & 3 & 6 & 3 \\
\hline Jordan & 53.6 & 74.0 & 4 & 82 & 78 \\
\hline Guatemala & 53.1 & 71.8 & 5 & 96 & 91 \\
\hline Maldives & 52.9 & 76.8 & 6 & 44 & 38 \\
\hline Sao Tome and Principe & 52.6 & 66.5 & 7 & 126 & 119 \\
\hline Panama & 52.5 & 77.6 & 8 & 37 & 29 \\
\hline Nicaragua & 52.4 & 74.9 & 9 & 64 & 55 \\
\hline Jamaica & 52.4 & 75.7 & 10 & 55 & 45 \\
\hline Algeria & 52.4 & 74.8 & 11 & 68 & 57 \\
\hline Vanuatu & 52.4 & 71.9 & 12 & 95 & 83 \\
\hline Timor-Leste & 52.3 & 68.2 & 13 & 122 & 109 \\
\hline Ecuador & 52.1 & 75.9 & 14 & 52 & 38 \\
\hline Costa Rica & 51.9 & 79.4 & 15 & 30 & 15 \\
\hline Iraq & 51.9 & 69.4 & 16 & 114 & 98 \\
\hline United Arab Emirates & 51.8 & 77.0 & 17 & 41 & 24 \\
\hline Mexico & 51.6 & 76.8 & 18 & 44 & 26 \\
\hline Bolivia (Plurinational State of) & 51.5 & 68.3 & 19 & 121 & 102 \\
\hline Senegal & 51.5 & 66.5 & 20 & 126 & 106 \\
\hline Niger & 51.5 & 61.4 & 21 & 150 & 129 \\
\hline Brunei Darussalam & 51.4 & 78.8 & 22 & 33 & 11 \\
\hline Saudi Arabia & 51.4 & 74.3 & 23 & 77 & 54 \\
\hline Samoa & 51.3 & 73.4 & 24 & 86 & 62 \\
\hline Tonga & 51.3 & 72.8 & 25 & 94 & 69 \\
\hline Ethiopia & 51.3 & 64.1 & 26 & 138 & 112 \\
\hline Tajikistan & 51.0 & 69.4 & 27 & 114 & 87 \\
\hline
\end{tabular}




\begin{tabular}{|c|c|c|c|c|c|}
\hline Country & LP & LEB & $\operatorname{Rank}_{L P}$ & $\operatorname{Rank}_{\mathrm{LEB}}$ & Diff. rankings \\
\hline Gabon & 50.9 & 64.4 & 28 & 136 & 108 \\
\hline Cabo Verde & 50.9 & 73.3 & 29 & 88 & 59 \\
\hline Rwanda & 50.8 & 64.2 & 30 & 137 & 107 \\
\hline Uganda & 50.7 & 58.5 & 31 & 158 & 127 \\
\hline Peru & 50.7 & 74.6 & 32 & 72 & 40 \\
\hline Viet Nam & 50.3 & 75.8 & 33 & 54 & 21 \\
\hline Dominican Republic & 50.3 & 73.5 & 34 & 84 & 50 \\
\hline Yemen & 50.2 & 63.8 & 35 & 139 & 104 \\
\hline Qatar & 50.1 & 78.2 & 36 & 35 & -1 \\
\hline Belize & 50.0 & 70.0 & 37 & 108 & 71 \\
\hline Madagascar & 50.0 & 65.1 & 38 & 132 & 94 \\
\hline Sudan & 50.0 & 63.5 & 39 & 141 & 102 \\
\hline Kuwait & 50.0 & 74.4 & 40 & 75 & 35 \\
\hline Iran (Islamic Republic of) & 49.9 & 75.4 & 41 & 58 & 17 \\
\hline Venezuela (Bolivarian Republic of) & 49.9 & 74.2 & 42 & 79 & 37 \\
\hline Egypt & 49.9 & 71.1 & 43 & 102 & 59 \\
\hline Chile & 49.9 & 81.7 & 44 & 14 & -30 \\
\hline Zambia & 49.7 & 60.1 & 45 & 153 & 108 \\
\hline Pakistan & 49.7 & 66.2 & 46 & 128 & 82 \\
\hline El Salvador & 49.7 & 73.0 & 47 & 91 & 44 \\
\hline Paraguay & 49.6 & 72.9 & 48 & 92 & 44 \\
\hline Bangladesh & 49.6 & 71.6 & 49 & 98 & 49 \\
\hline Turkey & 49.3 & 75.3 & 50 & 60 & 10 \\
\hline Morocco & 49.3 & 74.0 & 51 & 82 & 31 \\
\hline Bahrain & 49.3 & 76.6 & 52 & 46 & -6 \\
\hline Malaysia & 49.3 & 74.7 & 53 & 70 & 17 \\
\hline Mauritania & 49.2 & 63.1 & 54 & 143 & 89 \\
\hline Iceland & 49.2 & 82.6 & 55 & 4 & -51 \\
\hline Congo & 49.1 & 62.3 & 56 & 147 & 91 \\
\hline
\end{tabular}




\begin{tabular}{|c|c|c|c|c|c|}
\hline Country & $\mathrm{LP}$ & LEB & $\operatorname{Rank}_{\mathrm{LP}}$ & $\operatorname{Rank}_{\mathrm{LEB}}$ & Diff. rankings \\
\hline Democratic Republic of the Congo & 49.1 & 58.7 & 57 & 156 & 99 \\
\hline Colombia & 49.0 & 74.0 & 58 & 82 & 24 \\
\hline Ireland & 49.0 & 80.9 & 59 & 20 & -39 \\
\hline Comoros & 48.9 & 63.3 & 60 & 142 & 82 \\
\hline Libya & 48.8 & 71.6 & 61 & 98 & 37 \\
\hline Nepal & 48.8 & 69.6 & 62 & 110 & 48 \\
\hline Mali & 48.8 & 58.0 & 63 & 159 & 96 \\
\hline Burkina Faso & 48.7 & 58.7 & 64 & 156 & 92 \\
\hline Bahamas & 48.7 & 75.4 & 65 & 58 & -7 \\
\hline Kenya & 48.7 & 61.6 & 66 & 149 & 83 \\
\hline Lao Peoples Democratic Republic & 48.6 & 66.2 & 67 & 128 & 61 \\
\hline Namibia & 48.6 & 64.8 & 68 & 134 & 66 \\
\hline Benin & 48.6 & 59.6 & 69 & 154 & 85 \\
\hline Micronesia (Federated States of) & 48.6 & 69.1 & 70 & 117 & 47 \\
\hline Afghanistan & 48.6 & 60.4 & 71 & 152 & 81 \\
\hline Burundi & 48.4 & 56.7 & 72 & 163 & 91 \\
\hline Cambodia & 48.4 & 68.4 & 73 & 120 & 47 \\
\hline Antigua and Barbuda & 48.4 & 76.1 & 74 & 51 & -23 \\
\hline Eritrea & 48.3 & 63.7 & 75 & 140 & 65 \\
\hline United Republic of Tanzania & 48.2 & 65.0 & 76 & 133 & 57 \\
\hline Bhutan & 48.2 & 69.5 & 77 & 112 & 35 \\
\hline Philippines & 48.2 & 68.2 & 78 & 122 & 44 \\
\hline Kyrgyzstan & 48.2 & 70.6 & 79 & 105 & 26 \\
\hline Lebanon & 48.2 & 79.3 & 80 & 31 & -49 \\
\hline Brazil & 48.1 & 74.5 & 81 & 73 & -8 \\
\hline New Zealand & 48.1 & 81.8 & 82 & 12 & -70 \\
\hline Australia & 48.0 & 82.4 & 83 & 6 & -77 \\
\hline Argentina & 47.9 & 76.3 & 84 & 48 & -36 \\
\hline Haiti & 47.6 & 62.8 & 85 & 144 & 59 \\
\hline
\end{tabular}




\begin{tabular}{|c|c|c|c|c|c|}
\hline Country & $\mathrm{LP}$ & LEB & $\operatorname{Rank}_{L P}$ & $\operatorname{Rank}_{\mathrm{LEB}}$ & Diff. rankings \\
\hline Djibouti & 47.5 & 62.0 & 86 & 148 & 62 \\
\hline Albania & 47.3 & 77.8 & 87 & 36 & -51 \\
\hline Botswana & 47.2 & 64.5 & 88 & 135 & 47 \\
\hline Guinea & 47.2 & 58.8 & 89 & 155 & 66 \\
\hline Tunisia & 47.1 & 74.8 & 90 & 68 & -22 \\
\hline Suriname & 47.1 & 71.1 & 91 & 102 & 11 \\
\hline Zimbabwe & 46.8 & 57.5 & 92 & 161 & 69 \\
\hline Sri Lanka & 46.8 & 74.9 & 93 & 64 & -29 \\
\hline Ghana & 46.8 & 61.4 & 94 & 150 & 56 \\
\hline Cyprus & 46.7 & 80.2 & 95 & 28 & -67 \\
\hline Uzbekistan & 46.6 & 68.4 & 96 & 120 & 24 \\
\hline Norway & 46.5 & 81.6 & 97 & 16 & -81 \\
\hline India & 46.5 & 68.0 & 98 & 124 & 26 \\
\hline Mozambique & 46.4 & 55.1 & 99 & 165 & 66 \\
\hline France & 46.4 & 82.2 & 100 & 8 & -92 \\
\hline Azerbaijan & 46.4 & 70.8 & 101 & 104 & 3 \\
\hline Luxembourg & 46.4 & 81.7 & 102 & 14 & -88 \\
\hline Republic of Korea & 46.1 & 81.9 & 103 & 11 & -92 \\
\hline Malawi & 46.0 & 62.8 & 104 & 144 & 40 \\
\hline Syrian Arab Republic & 45.9 & 69.6 & 105 & 110 & 5 \\
\hline Saint Lucia & 45.9 & 75.1 & 106 & 62 & -44 \\
\hline Equatorial Guinea & 45.9 & 57.6 & 107 & 160 & 53 \\
\hline Uruguay & 45.9 & 77.2 & 108 & 40 & -68 \\
\hline Switzerland & 45.9 & 83.0 & 109 & 3 & -106 \\
\hline United States of America & 45.8 & 79.1 & 110 & 32 & -78 \\
\hline Mongolia & 45.7 & 69.4 & 111 & 114 & 3 \\
\hline Fiji & 45.6 & 70.0 & 112 & 108 & -4 \\
\hline Cameroon & 45.5 & 55.5 & 113 & 164 & 51 \\
\hline Grenada & 45.5 & 73.4 & 114 & 86 & -28 \\
\hline
\end{tabular}




\begin{tabular}{|c|c|c|c|c|c|}
\hline Country & LP & LEB & $\operatorname{Rank}_{\mathrm{LP}}$ & $\operatorname{Rank}_{\mathrm{LEB}}$ & Diff. rankings \\
\hline Sweden & 45.4 & 82.2 & 115 & 8 & -107 \\
\hline United Kingdom & 45.4 & 80.7 & 116 & 24 & -92 \\
\hline Saint Vincent and the Grenadines & 45.3 & 72.9 & 117 & 92 & -25 \\
\hline Canada & 45.2 & 82.0 & 118 & 10 & -108 \\
\hline Spain & 45.2 & 82.6 & 119 & 4 & -115 \\
\hline Mauritius & 45.1 & 74.4 & 120 & 75 & -45 \\
\hline Papua New Guinea & 45.0 & 62.6 & 121 & 146 & 25 \\
\hline Turkmenistan & 45.0 & 65.6 & 122 & 131 & 9 \\
\hline Angola & 45.0 & 52.3 & 123 & 167 & 44 \\
\hline Chad & 45.0 & 51.6 & 124 & 168 & 44 \\
\hline Netherlands & 45.0 & 81.6 & 125 & 16 & -109 \\
\hline Cuba & 44.7 & 79.4 & 126 & 30 & -96 \\
\hline Malta & 44.6 & 80.6 & 127 & 25 & -102 \\
\hline Belgium & 44.6 & 80.8 & 128 & 22 & -106 \\
\hline Myanmar & 44.5 & 65.9 & 129 & 130 & 1 \\
\hline Guyana & 44.3 & 66.4 & 130 & 127 & -3 \\
\hline Seychelles & 44.3 & 73.1 & 131 & 90 & -41 \\
\hline Indonesia & 44.3 & 68.9 & 132 & 118 & -14 \\
\hline Nigeria & 44.0 & 52.8 & 133 & 166 & 33 \\
\hline Kazakhstan & 44.0 & 69.4 & 134 & 114 & -20 \\
\hline China & 43.9 & 75.8 & 135 & 54 & -81 \\
\hline Denmark & 43.9 & 80.2 & 136 & 28 & -108 \\
\hline Thailand & 43.9 & 74.4 & 137 & 75 & -62 \\
\hline Portugal & 43.9 & 80.9 & 138 & 20 & -118 \\
\hline Finland & 43.7 & 80.8 & 139 & 22 & -117 \\
\hline Armenia & 43.6 & 74.7 & 140 & 70 & -70 \\
\hline Swaziland & 43.6 & 49.0 & 141 & 171 & 30 \\
\hline Austria & 43.4 & 81.4 & 142 & 17 & -125 \\
\hline Italy & 43.1 & 83.1 & 143 & 2 & -141 \\
\hline
\end{tabular}




\begin{tabular}{|c|c|c|c|c|c|}
\hline Country & LP & LEB & $\operatorname{Rank}_{\mathrm{LP}}$ & Rank $_{L E B}$ & Diff. rankings \\
\hline Barbados & 43.1 & 75.6 & 144 & 56 & -88 \\
\hline Central African Republic & 42.9 & 50.7 & 145 & 169 & 24 \\
\hline Japan & 42.3 & 83.5 & 146 & 1 & -145 \\
\hline The former Yugoslav republic of Macedonia & 42.2 & 75.4 & 147 & 58 & -89 \\
\hline South Africa & 42.2 & 57.4 & 148 & 162 & 14 \\
\hline Greece & 42.2 & 80.9 & 149 & 20 & -129 \\
\hline Slovenia & 42.1 & 80.4 & 150 & 26 & -124 \\
\hline Czech Republic & 41.8 & 78.6 & 151 & 34 & -117 \\
\hline Poland & 41.8 & 77.4 & 152 & 38 & -114 \\
\hline Trinidad and Tobago & 41.6 & 70.4 & 153 & 106 & -47 \\
\hline Slovakia & 41.6 & 76.3 & 154 & 48 & -106 \\
\hline Bosnia and Herzegovina & 41.3 & 76.5 & 155 & 47 & -108 \\
\hline Germany & 41.1 & 80.9 & 156 & 20 & -136 \\
\hline Georgia & 41.0 & 74.9 & 157 & 64 & -93 \\
\hline Estonia & 40.9 & 76.8 & 158 & 44 & -114 \\
\hline Croatia & 40.6 & 77.3 & 159 & 39 & -120 \\
\hline Montenegro & 40.5 & 76.2 & 160 & 50 & -110 \\
\hline Republic of Moldova & 40.5 & 71.6 & 161 & 98 & -63 \\
\hline Romania & 40.0 & 74.7 & 162 & 70 & -92 \\
\hline Hungary & 39.2 & 75.2 & 163 & 61 & -102 \\
\hline Serbia & 38.9 & 74.9 & 164 & 64 & -100 \\
\hline Lesotho & 38.6 & 49.8 & 165 & 170 & 5 \\
\hline Latvia & 38.3 & 74.2 & 166 & 79 & -87 \\
\hline Belarus & 38.3 & 71.3 & 167 & 100 & -67 \\
\hline Bulgaria & 38.2 & 74.2 & 168 & 79 & -89 \\
\hline Russian Federation & 37.9 & 70.1 & 169 & 107 & -62 \\
\hline Lithuania & 37.7 & 73.3 & 170 & 88 & -82 \\
\hline Ukraine & 37.4 & 71.0 & 171 & 103 & -68 \\
\hline
\end{tabular}


Table 5: Values and rankings for life potential and life expectancy at birth. 


\begin{tabular}{|c|c|c|c|c|c|c|c|c|}
\hline Country & $\mathrm{EP}$ & EYS & MYS & EI & $\mathrm{EI}_{\mathrm{UN}}$ & $\mathrm{R}_{\mathrm{EI}}$ & $\mathrm{R}_{\mathrm{EI}} \mathrm{UN}_{\mathrm{U}}$ & Diff. ranking \\
\hline Germany & 12.4 & 16.5 & 13.1 & 0.951 & 0.895 & 1 & 6 & 5 \\
\hline Lithuania & 11.9 & 16.4 & 12.4 & 0.917 & 0.869 & 2 & 12 & 10 \\
\hline Australia & 11.9 & 20.2 & 13.0 & 0.917 & 0.933 & 3 & 1 & -2 \\
\hline Denmark & 11.9 & 18.7 & 12.7 & 0.913 & 0.923 & 4 & 2 & -2 \\
\hline United Kingdom & 11.8 & 16.2 & 13.1 & 0.907 & 0.887 & 5 & 9 & 4 \\
\hline United States of America & 11.6 & 16.5 & 12.9 & 0.894 & 0.888 & 6 & 8 & 2 \\
\hline New Zealand & 11.6 & 19.2 & 12.5 & 0.893 & 0.917 & 7 & 3 & -4 \\
\hline Switzerland & 11.6 & 15.8 & 12.8 & 0.891 & 0.866 & 8 & 14 & 6 \\
\hline Canada & 11.5 & 15.9 & 13.0 & 0.887 & 0.875 & 9 & 10 & 1 \\
\hline Estonia & 11.5 & 16.5 & 12.5 & 0.883 & 0.875 & 10 & 10 & 0 \\
\hline Norway & 11.4 & 17.5 & 12.6 & 0.878 & 0.906 & 11 & 5 & -6 \\
\hline Czech Republic & 11.3 & 16.4 & 12.3 & 0.870 & 0.866 & 12 & 15 & 3 \\
\hline Belarus & 11.2 & 15.7 & 12.0 & 0.864 & 0.836 & 13 & 20 & 7 \\
\hline Republic of Korea & 11.2 & 16.9 & 11.9 & 0.862 & 0.866 & 14 & 13 & -1 \\
\hline Russian Federation & 11.2 & 14.7 & 12.0 & 0.861 & 0.808 & 15 & 28 & 13 \\
\hline Slovenia & 11.2 & 16.8 & 11.9 & 0.859 & 0.863 & 16 & 16 & 0 \\
\hline Netherlands & 11.2 & 17.9 & 11.9 & 0.858 & 0.894 & 17 & 7 & -10 \\
\hline Sweden & 11.1 & 15.8 & 12.1 & 0.857 & 0.842 & 18 & 19 & 1 \\
\hline Slovakia & 11.1 & 15.1 & 12.2 & 0.856 & 0.826 & 19 & 23 & 4 \\
\hline Belgium & 10.9 & 16.3 & 11.3 & 0.842 & 0.829 & 20 & 22 & 2 \\
\hline Poland & 10.9 & 15.5 & 11.8 & 0.835 & 0.824 & 21 & 24 & 3 \\
\hline Ireland & 10.7 & 18.6 & 12.2 & 0.823 & 0.907 & 22 & 4 & -18 \\
\hline Latvia & 10.6 & 15.2 & 11.5 & 0.818 & 0.806 & 23 & 30 & 7 \\
\hline Croatia & 10.6 & 14.8 & 11.0 & 0.812 & 0.778 & 24 & 38 & 14 \\
\hline Ukraine & 10.6 & 15.1 & 11.3 & 0.812 & 0.796 & 25 & 34 & 9 \\
\hline Israel & 10.6 & 16.0 & 12.5 & 0.812 & 0.861 & 26 & 17 & -9 \\
\hline Japan & 10.6 & 15.3 & 11.5 & 0.812 & 0.808 & 27 & 28 & 1 \\
\hline Austria & 10.4 & 15.7 & 10.8 & 0.802 & 0.796 & 28 & 34 & 6 \\
\hline
\end{tabular}




\begin{tabular}{|c|c|c|c|c|c|c|c|c|}
\hline Country & $\mathrm{EP}$ & EYS & MYS & EI & $\mathrm{EI}_{\mathrm{UN}}$ & $\mathrm{R}_{\mathrm{EI}}$ & $\mathrm{R}_{\mathrm{EI}_{\mathrm{UN}}}$ & Diff. ranking \\
\hline Georgia & 10.4 & 13.8 & 12.1 & 0.799 & 0.787 & 29 & 36 & 7 \\
\hline France & 10.3 & 16.0 & 11.1 & 0.794 & 0.814 & 30 & 27 & -3 \\
\hline Finland & 10.3 & 17.1 & 10.3 & 0.793 & 0.818 & 31 & 26 & -5 \\
\hline Montenegro & 10.2 & 15.2 & 11.2 & 0.788 & 0.796 & 32 & 35 & 3 \\
\hline Iceland & 10.2 & 19.0 & 10.6 & 0.787 & 0.853 & 33 & 18 & -15 \\
\hline Luxembourg & 10.2 & 13.9 & 11.7 & 0.783 & 0.776 & 34 & 40 & 6 \\
\hline Bulgaria & 10.1 & 14.4 & 10.6 & 0.779 & 0.753 & 35 & 46 & 11 \\
\hline Greece & 10.0 & 17.6 & 10.3 & 0.773 & 0.832 & 36 & 21 & -15 \\
\hline Cyprus & 10.0 & 14.0 & 11.6 & 0.773 & 0.776 & 37 & 41 & 4 \\
\hline Cuba & 10.0 & 13.8 & 11.5 & 0.771 & 0.767 & 38 & 42 & 4 \\
\hline Romania & 10.0 & 14.2 & 10.8 & 0.769 & 0.754 & 39 & 45 & 6 \\
\hline Kazakhstan & 9.9 & 15.0 & 11.4 & 0.763 & 0.797 & 40 & 32 & -8 \\
\hline Serbia & 9.9 & 14.4 & 10.5 & 0.760 & 0.750 & 41 & 47 & 6 \\
\hline Republic of Moldova & 9.8 & 11.9 & 11.2 & 0.755 & 0.704 & 42 & 64 & 22 \\
\hline Italy & 9.6 & 16.0 & 10.1 & 0.741 & 0.781 & 43 & 37 & -6 \\
\hline Armenia & 9.6 & 12.3 & 10.9 & 0.735 & 0.705 & 44 & 61 & 17 \\
\hline Azerbaijan & 9.4 & 11.9 & 11.2 & 0.721 & 0.704 & 45 & 64 & 19 \\
\hline Uzbekistan & 9.3 & 11.5 & 10.9 & 0.719 & 0.683 & 46 & 75 & 29 \\
\hline Chile & 9.3 & 15.2 & 9.8 & 0.718 & 0.749 & 47 & 48 & 1 \\
\hline Barbados & 9.3 & 15.4 & 10.5 & 0.717 & 0.778 & 48 & 38 & -10 \\
\hline Sri Lanka & 9.3 & 13.7 & 10.8 & 0.714 & 0.741 & 49 & 50 & 1 \\
\hline Spain & 9.3 & 17.3 & 9.6 & 0.713 & 0.801 & 50 & 31 & -19 \\
\hline Argentina & 9.2 & 17.9 & 9.8 & 0.711 & 0.824 & 51 & 24 & -27 \\
\hline Kyrgyzstan & 9.0 & 12.5 & 10.6 & 0.696 & 0.701 & 52 & 66 & 14 \\
\hline Albania & 8.9 & 11.8 & 9.3 & 0.687 & 0.638 & 53 & 96 & 43 \\
\hline Trinidad and Tobago & 8.9 & 12.3 & 10.9 & 0.682 & 0.705 & 54 & 61 & 7 \\
\hline Bahamas & 8.6 & 12.6 & 10.9 & 0.661 & 0.713 & 55 & 58 & 3 \\
\hline Mongolia & 8.5 & 14.6 & 9.3 & 0.652 & 0.716 & 56 & 55 & -1 \\
\hline The former Yugoslav republic of Macedonia & 8.5 & 13.4 & 9.3 & 0.651 & 0.682 & 57 & 76 & 19 \\
\hline
\end{tabular}




\begin{tabular}{|c|c|c|c|c|c|c|c|c|}
\hline Country & $\mathrm{EP}$ & EYS & MYS & EI & $\mathrm{EI}_{\mathrm{UN}}$ & $\mathrm{R}_{\mathrm{EI}}$ & $\mathrm{R}_{\mathrm{EI}} \mathrm{UN}_{\mathrm{N}}$ & Diff. ranking \\
\hline Tajikistan & 8.4 & 11.2 & 10.4 & 0.645 & 0.658 & 58 & 84 & 26 \\
\hline Turkey & 8.4 & 14.5 & 7.6 & 0.643 & 0.656 & 59 & 85 & 26 \\
\hline Tonga & 8.3 & 14.7 & 10.7 & 0.637 & 0.765 & 60 & 44 & -16 \\
\hline Malaysia & 8.2 & 12.7 & 10.0 & 0.634 & 0.686 & 61 & 72 & 11 \\
\hline Venezuela (Bolivarian Republic of) & 8.1 & 14.2 & 8.9 & 0.625 & 0.691 & 62 & 70 & 8 \\
\hline Fiji & 8.1 & 15.7 & 9.9 & 0.623 & 0.766 & 63 & 43 & -20 \\
\hline Turkmenistan & 8.1 & 10.8 & 9.9 & 0.622 & 0.630 & 64 & 99 & 35 \\
\hline Bahrain & 8.0 & 14.4 & 9.4 & 0.615 & 0.713 & 65 & 58 & -7 \\
\hline Uruguay & 8.0 & 15.5 & 8.5 & 0.614 & 0.714 & 66 & 56 & -10 \\
\hline Portugal & 8.0 & 16.3 & 8.2 & 0.612 & 0.726 & 67 & 52 & -15 \\
\hline Bosnia and Herzegovina & 7.9 & 13.6 & 8.3 & 0.611 & 0.654 & 68 & 86 & 18 \\
\hline Saudi Arabia & 7.9 & 16.3 & 8.7 & 0.608 & 0.743 & 69 & 49 & -20 \\
\hline Jordan & 7.9 & 13.5 & 9.9 & 0.604 & 0.705 & 70 & 61 & -9 \\
\hline Samoa & 7.8 & 12.9 & 10.3 & 0.604 & 0.702 & 71 & 65 & -6 \\
\hline Brunei Darussalam & 7.8 & 14.5 & 8.8 & 0.603 & 0.696 & 72 & 67 & -5 \\
\hline Qatar & 7.8 & 13.8 & 9.1 & 0.601 & 0.687 & 73 & 71 & -2 \\
\hline South Africa & 7.8 & 13.6 & 9.9 & 0.601 & 0.708 & 74 & 59 & -15 \\
\hline Mauritius & 7.8 & 15.6 & 8.5 & 0.599 & 0.717 & 75 & 54 & -21 \\
\hline United Arab Emirates & 7.7 & 13.3 & 9.5 & 0.596 & 0.686 & 76 & 72 & -4 \\
\hline Seychelles & 7.7 & 13.4 & 9.4 & 0.594 & 0.686 & 77 & 74 & -3 \\
\hline Grenada & 7.7 & 15.8 & 8.6 & 0.593 & 0.726 & 78 & 53 & -25 \\
\hline Costa Rica & 7.7 & 13.9 & 8.4 & 0.590 & 0.666 & 79 & 80 & 1 \\
\hline Panama & 7.6 & 13.3 & 9.3 & 0.587 & 0.679 & 80 & 77 & -3 \\
\hline Antigua and Barbuda & 7.6 & 14.0 & 9.2 & 0.584 & 0.696 & 81 & 68 & -13 \\
\hline Belize & 7.6 & 13.6 & 10.5 & 0.582 & 0.728 & 82 & 51 & -31 \\
\hline Saint Lucia & 7.5 & 12.6 & 9.3 & 0.580 & 0.660 & 83 & 82 & -1 \\
\hline Iran (Islamic Republic of) & 7.5 & 15.1 & 8.2 & 0.579 & 0.693 & 84 & 69 & -15 \\
\hline Brazil & 7.5 & 15.2 & 7.7 & 0.578 & 0.679 & 85 & 78 & -7 \\
\hline Peru & 7.4 & 13.1 & 9.0 & 0.572 & 0.664 & 86 & 81 & -5 \\
\hline
\end{tabular}




\begin{tabular}{|c|c|c|c|c|c|c|c|c|}
\hline Country & $\mathrm{EP}$ & EYS & MYS & EI & $\mathrm{EI}_{\mathrm{UN}}$ & $\mathrm{R}_{\mathrm{EI}}$ & $\mathrm{R}_{\mathrm{EI}_{\mathrm{UN}}}$ & Diff. ranking \\
\hline Micronesia (Federated States of) & 7.4 & 11.7 & 9.7 & 0.571 & 0.648 & 87 & 88 & 1 \\
\hline Jamaica & 7.3 & 12.4 & 9.7 & 0.564 & 0.668 & 88 & 79 & -9 \\
\hline Mexico & 7.2 & 13.1 & 8.5 & 0.556 & 0.647 & 89 & 90 & 1 \\
\hline Libya & 7.1 & 14.0 & 7.3 & 0.548 & 0.632 & 90 & 98 & 8 \\
\hline Saint Vincent and the Grenadines & 7.1 & 13.4 & 8.6 & 0.545 & 0.659 & 91 & 83 & -8 \\
\hline Ecuador & 7.1 & 14.2 & 7.6 & 0.544 & 0.648 & 92 & 89 & -3 \\
\hline Algeria & 7.0 & 14.0 & 7.6 & 0.542 & 0.642 & 93 & 94 & 1 \\
\hline Bolivia (Plurinational State of) & 7.0 & 13.2 & 8.2 & 0.538 & 0.640 & 94 & 95 & 1 \\
\hline Colombia & 6.9 & 13.5 & 7.3 & 0.533 & 0.618 & 95 & 100 & 5 \\
\hline Oman & 6.9 & 13.6 & 8.0 & 0.530 & 0.644 & 96 & 92 & -4 \\
\hline China & 6.9 & 13.1 & 7.5 & 0.530 & 0.614 & 97 & 104 & 7 \\
\hline Botswana & 6.9 & 12.5 & 8.9 & 0.528 & 0.644 & 98 & 93 & -5 \\
\hline Philippines & 6.9 & 11.3 & 8.9 & 0.528 & 0.611 & 99 & 105 & 6 \\
\hline Thailand & 6.8 & 13.5 & 7.3 & 0.524 & 0.618 & 100 & 100 & 0 \\
\hline Lebanon & 6.8 & 13.8 & 7.9 & 0.523 & 0.647 & 101 & 91 & -10 \\
\hline Dominican Republic & 6.7 & 13.1 & 7.6 & 0.518 & 0.617 & 102 & 102 & 0 \\
\hline Indonesia & 6.6 & 13.0 & 7.6 & 0.511 & 0.614 & 103 & 103 & 0 \\
\hline Suriname & 6.6 & 12.7 & 7.7 & 0.508 & 0.609 & 104 & 106 & 2 \\
\hline Paraguay & 6.6 & 11.9 & 7.7 & 0.508 & 0.587 & 105 & 110 & 5 \\
\hline Guyana & 6.6 & 10.3 & 8.5 & 0.505 & 0.569 & 106 & 112 & 6 \\
\hline Tunisia & 6.4 & 14.6 & 6.8 & 0.493 & 0.632 & 107 & 98 & -9 \\
\hline Kuwait & 6.4 & 14.7 & 7.2 & 0.492 & 0.648 & 108 & 87 & -21 \\
\hline Viet Nam & 6.3 & 11.9 & 7.5 & 0.482 & 0.581 & 109 & 111 & 2 \\
\hline El Salvador & 6.0 & 12.3 & 6.5 & 0.462 & 0.558 & 110 & 113 & 3 \\
\hline Egypt & 5.9 & 13.5 & 6.6 & 0.453 & 0.595 & 111 & 108 & -3 \\
\hline Gabon & 5.8 & 12.5 & 7.8 & 0.448 & 0.607 & 112 & 107 & -5 \\
\hline Ghana & 5.7 & 11.5 & 7.0 & 0.437 & 0.553 & 113 & 115 & 2 \\
\hline Vanuatu & 5.5 & 10.6 & 6.8 & 0.425 & 0.521 & 114 & 120 & 6 \\
\hline Swaziland & 5.3 & 11.3 & 7.1 & 0.410 & 0.551 & 115 & 117 & 2 \\
\hline
\end{tabular}




\begin{tabular}{|c|c|c|c|c|c|c|c|c|}
\hline Country & $\mathrm{EP}$ & EYS & MYS & EI & $\mathrm{EI}_{\mathrm{UN}}$ & $\mathrm{R}_{\mathrm{EI}}$ & $\mathrm{R}_{\mathrm{EI}_{\mathrm{UN}}}$ & Diff. ranking \\
\hline Syrian Arab Republic & 5.3 & 12.3 & 6.3 & 0.409 & 0.552 & 116 & 116 & 0 \\
\hline Zimbabwe & 5.2 & 10.9 & 7.3 & 0.400 & 0.546 & 117 & 118 & 1 \\
\hline Namibia & 5.1 & 11.3 & 6.2 & 0.395 & 0.521 & 118 & 121 & 3 \\
\hline Kenya & 5.0 & 11.0 & 6.3 & 0.387 & 0.516 & 119 & 123 & 4 \\
\hline Cameroon & 5.0 & 10.4 & 6.0 & 0.387 & 0.489 & 120 & 128 & 8 \\
\hline Iraq & 5.0 & 10.1 & 6.4 & 0.387 & 0.494 & 121 & 126 & 5 \\
\hline Nicaragua & 5.0 & 11.5 & 6.0 & 0.386 & 0.519 & 122 & 122 & 0 \\
\hline Cabo Verde & 5.0 & 13.5 & 4.7 & 0.385 & 0.532 & 123 & 119 & -4 \\
\hline India & 5.0 & 11.7 & 5.4 & 0.384 & 0.505 & 124 & 125 & 1 \\
\hline Congo & 5.0 & 11.1 & 6.1 & 0.384 & 0.512 & 125 & 124 & -1 \\
\hline Sao Tome and Principe & 5.0 & 11.3 & 4.7 & 0.383 & 0.471 & 126 & 135 & 9 \\
\hline Timor-Leste & 4.8 & 11.7 & 4.4 & 0.373 & 0.472 & 127 & 134 & 7 \\
\hline Maldives & 4.8 & 13.0 & 5.8 & 0.370 & 0.554 & 128 & 114 & -14 \\
\hline Honduras & 4.8 & 11.1 & 5.5 & 0.366 & 0.492 & 129 & 127 & -2 \\
\hline Guatemala & 4.7 & 10.7 & 5.6 & 0.359 & 0.484 & 130 & 130 & 0 \\
\hline Madagascar & 4.5 & 10.3 & 6.0 & 0.349 & 0.486 & 131 & 129 & -2 \\
\hline Lao Peoples Democratic Republic & 4.5 & 10.6 & 5.0 & 0.346 & 0.461 & 132 & 137 & 5 \\
\hline Bangladesh & 4.5 & 10.0 & 5.1 & 0.345 & 0.448 & 133 & 142 & 9 \\
\hline Zambia & 4.5 & 13.5 & 6.6 & 0.344 & 0.595 & 134 & 108 & -26 \\
\hline Comoros & 4.4 & 11.5 & 4.6 & 0.341 & 0.473 & 135 & 132 & -3 \\
\hline Democratic Republic of the Congo & 4.4 & 9.8 & 6.0 & 0.337 & 0.472 & 136 & 133 & -3 \\
\hline Morocco & 4.3 & 11.6 & 4.4 & 0.333 & 0.469 & 137 & 136 & -1 \\
\hline Nigeria & 4.3 & 9.0 & 5.9 & 0.331 & 0.447 & 138 & 143 & 5 \\
\hline Uganda & 4.2 & 9.8 & 5.4 & 0.320 & 0.452 & 139 & 139 & 0 \\
\hline Malawi & 4.0 & 10.8 & 4.3 & 0.310 & 0.443 & 140 & 144 & 4 \\
\hline Equatorial Guinea & 4.0 & 9.0 & 5.5 & 0.305 & 0.433 & 141 & 145 & 4 \\
\hline Benin & 3.9 & 11.1 & 3.3 & 0.303 & 0.418 & 142 & 147 & 5 \\
\hline Angola & 3.9 & 11.4 & 4.7 & 0.301 & 0.473 & 143 & 131 & -12 \\
\hline United Republic of Tanzania & 3.9 & 9.2 & 5.1 & 0.299 & 0.426 & 144 & 146 & 2 \\
\hline
\end{tabular}




\begin{tabular}{|c|c|c|c|c|c|c|c|c|}
\hline Country & EP & EYS & MYS & EI & $\mathrm{EI}_{\mathrm{UN}}$ & $\mathrm{R}_{\mathrm{EI}}$ & $\mathrm{R}_{\mathrm{EI}_{\mathrm{UN}}}$ & Diff. ranking \\
\hline Cambodia & 3.9 & 10.9 & 4.4 & 0.298 & 0.449 & 145 & 141 & -4 \\
\hline Nepal & 3.8 & 12.4 & 3.3 & 0.292 & 0.454 & 146 & 138 & -8 \\
\hline Pakistan & 3.7 & 7.8 & 4.7 & 0.284 & 0.373 & 147 & 152 & 5 \\
\hline Papua New Guinea & 3.7 & 9.9 & 4.0 & 0.284 & 0.408 & 148 & 149 & 1 \\
\hline Rwanda & 3.6 & 10.3 & 3.7 & 0.278 & 0.409 & 149 & 148 & -1 \\
\hline Bhutan & 3.6 & 12.6 & 3.0 & 0.278 & 0.450 & 150 & 140 & -10 \\
\hline Afghanistan & 3.6 & 9.3 & 3.2 & 0.274 & 0.365 & 151 & 154 & 3 \\
\hline Haiti & 3.5 & 8.7 & 4.9 & 0.272 & 0.405 & 152 & 150 & -2 \\
\hline Myanmar & 3.5 & 8.6 & 4.1 & 0.272 & 0.376 & 153 & 151 & -2 \\
\hline Burundi & 3.3 & 10.1 & 2.7 & 0.254 & 0.371 & 154 & 153 & -1 \\
\hline Djibouti & 3.3 & 6.4 & 3.8 & 0.252 & 0.304 & 155 & 161 & 6 \\
\hline Mauritania & 3.3 & 8.5 & 3.8 & 0.251 & 0.363 & 156 & 156 & 0 \\
\hline Mozambique & 3.1 & 9.3 & 3.2 & 0.240 & 0.365 & 157 & 154 & -3 \\
\hline Central African Republic & 3.1 & 7.2 & 4.2 & 0.239 & 0.340 & 158 & 158 & 0 \\
\hline Eritrea & 3.1 & 4.1 & 3.9 & 0.235 & 0.244 & 159 & 167 & 8 \\
\hline Yemen & 3.0 & 9.2 & 2.6 & 0.230 & 0.342 & 160 & 157 & -3 \\
\hline Sudan & 2.9 & 7.0 & 3.1 & 0.221 & 0.298 & 161 & 164 & 3 \\
\hline Guinea & 2.9 & 8.7 & 2.4 & 0.219 & 0.322 & 162 & 159 & -3 \\
\hline Senegal & 2.8 & 7.9 & 2.5 & 0.212 & 0.303 & 163 & 162 & -1 \\
\hline Ethiopia & 2.7 & 8.5 & 2.4 & 0.211 & 0.316 & 164 & 160 & -4 \\
\hline Mali & 2.5 & 8.4 & 2.0 & 0.195 & 0.300 & 165 & 163 & -2 \\
\hline Chad & 2.3 & 7.4 & 1.9 & 0.180 & 0.269 & 166 & 165 & -1 \\
\hline Burkina Faso & 2.1 & 7.8 & 1.4 & 0.165 & 0.263 & 167 & 166 & -1 \\
\hline Niger & 1.8 & 5.4 & 1.5 & 0.141 & 0.200 & 168 & 168 & 0 \\
\hline
\end{tabular}

Table 6: Values and rankings for MYS, EYS, EP, and its partial indices. 


\begin{tabular}{|c|c|c|c|c|c|}
\hline Country & GNIpa & GNIpc & $\mathrm{R}_{\mathrm{GNIpa}}$ & $\mathrm{R}_{\mathrm{GNIpc}}$ & Diff. ranking \\
\hline Qatar & 144217.91 & 123124 & 1 & 1 & 0 \\
\hline Kuwait & 118210.93 & 83961 & 2 & 2 & 0 \\
\hline Brunei Darussalam & 101779.08 & 72570 & 3 & 3 & 0 \\
\hline Norway & 83107.19 & 64992 & 4 & 4 & 0 \\
\hline United Arab Emirates & 79848.12 & 60868 & 5 & 5 & 0 \\
\hline Saudi Arabia & 78253.38 & 52821 & 6 & 9 & 3 \\
\hline Luxembourg & 73842.55 & 58711 & 7 & 6 & -1 \\
\hline Switzerland & 69081.72 & 56431 & 8 & 7 & -1 \\
\hline United States of America & 68684.29 & 52947 & 9 & 8 & -1 \\
\hline Sweden & 57168.05 & 45636 & 10 & 10 & 0 \\
\hline Netherlands & 57025.59 & 45435 & 11 & 11 & 0 \\
\hline Denmark & 55452.39 & 44025 & 12 & 12 & 0 \\
\hline Oman & 54305.86 & 34858 & 13 & 25 & 12 \\
\hline Australia & 53865.87 & 42261 & 14 & 15 & 1 \\
\hline Austria & 52911.48 & 43869 & 15 & 14 & -1 \\
\hline Ireland & 52868.87 & 39568 & 16 & 18 & 2 \\
\hline Germany & 52178.05 & 43919 & 17 & 13 & -4 \\
\hline Canada & 51895.04 & 42155 & 18 & 16 & -2 \\
\hline Belgium & 51717.67 & 41187 & 19 & 17 & -2 \\
\hline Bahrain & 50551.16 & 38599 & 20 & 21 & 1 \\
\hline United Kingdom & 49557.53 & 39267 & 21 & 19 & -2 \\
\hline France & 48946.64 & 38056 & 22 & 22 & 0 \\
\hline Finland & 48169.72 & 38695 & 23 & 20 & -3 \\
\hline Iceland & 46542.23 & 35182 & 24 & 24 & 0 \\
\hline Israel & 45696.65 & 30676 & 25 & 30 & 5 \\
\hline Japan & 43955.34 & 36927 & 26 & 23 & -3 \\
\hline New Zealand & 42945.10 & 32689 & 27 & 28 & 1 \\
\hline Republic of Korea & 41082.44 & 33890 & 28 & 26 & -2 \\
\hline
\end{tabular}




\begin{tabular}{|c|c|c|c|c|c|}
\hline Country & GNIpa & GNIpc & $\mathrm{R}_{\text {GNIpa }}$ & $\mathrm{R}_{\mathrm{GNIpc}}$ & Diff. ranking \\
\hline Equatorial Guinea & 39713.21 & 21056 & 29 & 48 & 19 \\
\hline Italy & 39579.33 & 33030 & 30 & 27 & -3 \\
\hline Spain & 39189.55 & 32045 & 31 & 29 & -2 \\
\hline Cyprus & 35377.50 & 28633 & 32 & 31 & -1 \\
\hline Malaysia & 34355.94 & 22762 & 33 & 42 & 9 \\
\hline Trinidad and Tobago & 33897.76 & 26090 & 34 & 34 & 0 \\
\hline Slovenia & 33193.50 & 27852 & 35 & 32 & -3 \\
\hline Czech Republic & 32360.41 & 26660 & 36 & 33 & -3 \\
\hline Gabon & 31948.94 & 16367 & 37 & 61 & 24 \\
\hline Portugal & 31837.33 & 25757 & 38 & 36 & -2 \\
\hline Slovakia & 31620.53 & 25845 & 39 & 35 & -4 \\
\hline Argentina & 31322.25 & 22050 & 40 & 45 & 5 \\
\hline Estonia & 30957.03 & 25214 & 41 & 37 & -4 \\
\hline Seychelles & 30808.24 & 23300 & 42 & 40 & -2 \\
\hline Lithuania & 29960.11 & 24500 & 43 & 39 & -4 \\
\hline Bahamas & 29605.19 & 21336 & 44 & 46 & 2 \\
\hline Kazakhstan & 29508.32 & 20867 & 45 & 49 & 4 \\
\hline Greece & 29491.50 & 24524 & 46 & 38 & -8 \\
\hline Chile & 28370.32 & 21290 & 47 & 47 & 0 \\
\hline Antigua and Barbuda & 28342.13 & 20070 & 48 & 50 & 2 \\
\hline Poland & 28161.45 & 23177 & 49 & 41 & -8 \\
\hline Russian Federation & 27705.13 & 22352 & 50 & 43 & -7 \\
\hline Botswana & 27380.73 & 16646 & 51 & 58 & 7 \\
\hline Latvia & 26987.74 & 22281 & 52 & 44 & -8 \\
\hline Panama & 26910.15 & 18192 & 53 & 54 & 1 \\
\hline Turkey & 26857.97 & 18677 & 54 & 53 & -1 \\
\hline Iraq & 26249.63 & 14003 & 55 & 70 & 15 \\
\hline Uruguay & 25874.07 & 19283 & 56 & 52 & -4 \\
\hline Venezuela (Bolivarian Republic of) & 24209.75 & 16159 & 57 & 62 & 5 \\
\hline
\end{tabular}




\begin{tabular}{|c|c|c|c|c|c|}
\hline Country & GNIpa & GNIpc & $\mathrm{R}_{\mathrm{GNIpa}}$ & $\mathrm{R}_{\mathrm{GNIpc}}$ & Diff. ranking \\
\hline Mexico & 23986.39 & 16056 & 58 & 63 & 5 \\
\hline Lebanon & 23624.09 & 16509 & 59 & 59 & 0 \\
\hline Croatia & 23559.55 & 19409 & 60 & 51 & -9 \\
\hline Mauritius & 23319.33 & 17470 & 61 & 56 & -5 \\
\hline Suriname & 22748.90 & 15617 & 62 & 64 & 2 \\
\hline Azerbaijan & 22470.95 & 16428 & 63 & 60 & -3 \\
\hline Romania & 21991.19 & 18108 & 64 & 55 & -9 \\
\hline Libya & 21872.10 & 14911 & 65 & 68 & 3 \\
\hline Iran (Islamic Republic of) & 21458.47 & 15440 & 66 & 66 & 0 \\
\hline Brazil & 21179.08 & 15175 & 67 & 67 & 0 \\
\hline Belarus & 20426.92 & 16676 & 68 & 57 & -11 \\
\hline Jordan & 19538.87 & 11365 & 69 & 83 & 14 \\
\hline Algeria & 19511.21 & 13054 & 70 & 74 & 4 \\
\hline Turkmenistan & 19073.50 & 13066 & 71 & 73 & 2 \\
\hline Bulgaria & 18846.54 & 15596 & 72 & 65 & -7 \\
\hline Costa Rica & 18643.82 & 13413 & 73 & 71 & -2 \\
\hline South Africa & 18291.10 & 12122 & 74 & 79 & 5 \\
\hline Dominican Republic & 17799.42 & 11883 & 75 & 81 & 6 \\
\hline Montenegro & 17750.21 & 14558 & 76 & 69 & -7 \\
\hline Colombia & 17250.50 & 12040 & 77 & 80 & 3 \\
\hline Egypt & 17159.67 & 10512 & 78 & 88 & 10 \\
\hline Thailand & 16971.14 & 13323 & 79 & 72 & -7 \\
\hline Namibia & 16890.90 & 9418 & 80 & 96 & 16 \\
\hline Maldives & 16716.97 & 12328 & 81 & 77 & -4 \\
\hline Peru & 16304.45 & 11015 & 82 & 84 & 2 \\
\hline Barbados & 16024.19 & 12488 & 83 & 76 & -7 \\
\hline Ecuador & 16011.32 & 10605 & 84 & 87 & 3 \\
\hline China & 15824.61 & 12547 & 85 & 75 & -10 \\
\hline Mongolia & 15727.47 & 10729 & 86 & 86 & 0 \\
\hline
\end{tabular}




\begin{tabular}{|c|c|c|c|c|c|}
\hline Country & GNIpa & GNIpc & $\mathrm{R}_{\mathrm{GNIpa}}$ & $\mathrm{R}_{\mathrm{GNIpc}}$ & Diff. ranking \\
\hline Grenada & 15403.07 & 10939 & 87 & 85 & -2 \\
\hline The former Yugoslav republic of Macedonia & 14995.16 & 11780 & 88 & 82 & -6 \\
\hline Serbia & 14841.52 & 12190 & 89 & 78 & -11 \\
\hline Tunisia & 14302.42 & 10404 & 90 & 89 & -1 \\
\hline Indonesia & 14215.18 & 9788 & 91 & 92 & 1 \\
\hline Sri Lanka & 13753.78 & 9779 & 92 & 93 & 1 \\
\hline Saint Vincent and the Grenadines & 13667.19 & 9937 & 93 & 91 & -2 \\
\hline Angola & 13636.22 & 6822 & 94 & 110 & 16 \\
\hline Philippines & 13229.95 & 7915 & 95 & 99 & 4 \\
\hline Saint Lucia & 13090.54 & 9765 & 96 & 94 & -2 \\
\hline Albania & 13062.53 & 9943 & 97 & 90 & -7 \\
\hline Belize & 12995.36 & 7614 & 98 & 101 & 3 \\
\hline Guatemala & 12039.47 & 6929 & 99 & 108 & 9 \\
\hline Bosnia and Herzegovina & 11618.19 & 9638 & 100 & 95 & -5 \\
\hline Congo & 11313.89 & 6012 & 101 & 113 & 12 \\
\hline Jamaica & 11279.83 & 7415 & 102 & 103 & 1 \\
\hline Fiji & 11174.52 & 7493 & 103 & 102 & -1 \\
\hline Paraguay & 11134.82 & 7643 & 104 & 100 & -4 \\
\hline El Salvador & 11085.00 & 7349 & 105 & 104 & -1 \\
\hline Bhutan & 10625.16 & 7176 & 106 & 106 & 0 \\
\hline Nigeria & 10578.49 & 5341 & 107 & 119 & 12 \\
\hline Armenia & 10515.04 & 8124 & 108 & 98 & -10 \\
\hline Timor-Leste & 10460.00 & 5363 & 109 & 118 & 9 \\
\hline Guyana & 10040.16 & 6522 & 110 & 111 & 1 \\
\hline Morocco & 10025.72 & 6850 & 111 & 109 & -2 \\
\hline Ukraine & 9958.15 & 8178 & 112 & 97 & -15 \\
\hline Swaziland & 9703.99 & 5542 & 113 & 116 & 3 \\
\hline Cabo Verde & 9582.25 & 6094 & 114 & 112 & -2 \\
\hline Bolivia (Plurinational State of) & 9442.39 & 5760 & 115 & 114 & -1 \\
\hline
\end{tabular}




\begin{tabular}{|c|c|c|c|c|c|}
\hline Country & GNIpa & GNIpc & $\mathrm{R}_{\text {GNIpa }}$ & $\mathrm{R}_{\mathrm{GNIpc}}$ & Diff. ranking \\
\hline Cuba & 9201.36 & 7301 & 116 & 105 & -11 \\
\hline Georgia & 9084.83 & 7164 & 117 & 107 & -10 \\
\hline Samoa & 8740.65 & 5327 & 118 & 120 & 2 \\
\hline Tonga & 8675.41 & 5069 & 119 & 123 & 4 \\
\hline India & 8288.46 & 5497 & 120 & 117 & -3 \\
\hline Pakistan & 8021.11 & 4866 & 121 & 124 & 3 \\
\hline Uzbekistan & 7933.28 & 5567 & 122 & 115 & -7 \\
\hline Lao Peoples Democratic Republic & 7928.85 & 4680 & 123 & 125 & 2 \\
\hline Zambia & 7911.68 & 3734 & 124 & 131 & 7 \\
\hline Sudan & 7207.45 & 3809 & 125 & 130 & 5 \\
\hline Viet Nam & 7149.92 & 5092 & 126 & 122 & -4 \\
\hline Ghana & 6945.38 & 3852 & 127 & 129 & 2 \\
\hline Nicaragua & 6851.48 & 4457 & 128 & 127 & -1 \\
\hline Yemen & 6775.80 & 3519 & 129 & 133 & 4 \\
\hline Myanmar & 6715.34 & 4608 & 130 & 126 & -4 \\
\hline Honduras & 6664.32 & 3938 & 131 & 128 & -3 \\
\hline Republic of Moldova & 6638.81 & 5223 & 132 & 121 & -11 \\
\hline Mauritania & 6554.59 & 3560 & 133 & 132 & -1 \\
\hline Sao Tome and Principe & 5849.75 & 2918 & 134 & 139 & 5 \\
\hline Micronesia (Federated States of) & 5528.19 & 3432 & 135 & 134 & -1 \\
\hline Cameroon & 5519.29 & 2803 & 136 & 140 & 4 \\
\hline Djibouti & 5355.62 & 3276 & 137 & 135 & -2 \\
\hline Kenya & 5273.47 & 2762 & 138 & 142 & 4 \\
\hline Vanuatu & 4938.50 & 2803 & 139 & 140 & 1 \\
\hline United Republic of Tanzania & 4923.90 & 2411 & 140 & 146 & 6 \\
\hline Bangladesh & 4920.37 & 3191 & 141 & 136 & -5 \\
\hline Kyrgyzstan & 4682.96 & 3044 & 142 & 137 & -5 \\
\hline Cambodia & 4669.09 & 2949 & 143 & 138 & -5 \\
\hline Syrian Arab Republic & 4459.88 & 2728 & 144 & 143 & -1 \\
\hline
\end{tabular}




\begin{tabular}{|c|c|c|c|c|c|}
\hline Country & GNIpa & GNIpc & $\mathrm{R}_{\mathrm{GNIpa}}$ & $\mathrm{R}_{\mathrm{GNIpc}}$ & Diff. ranking \\
\hline Chad & 4295.12 & 2085 & 145 & 149 & 4 \\
\hline Senegal & 4279.13 & 2188 & 146 & 148 & 2 \\
\hline Papua New Guinea & 4166.04 & 2463 & 147 & 145 & -2 \\
\hline Tajikistan & 4113.14 & 2517 & 148 & 144 & -4 \\
\hline Nepal & 3758.76 & 2311 & 149 & 147 & -2 \\
\hline Afghanistan & 3705.82 & 1885 & 150 & 150 & 0 \\
\hline Uganda & 3629.70 & 1613 & 151 & 154 & 3 \\
\hline Benin & 3552.95 & 1767 & 152 & 151 & -1 \\
\hline Mali & 3449.12 & 1583 & 153 & 156 & 3 \\
\hline Burkina Faso & 3309.91 & 1591 & 154 & 155 & 1 \\
\hline Zimbabwe & 2914.22 & 1615 & 155 & 153 & -2 \\
\hline Ethiopia & 2898.05 & 1428 & 156 & 159 & 3 \\
\hline Haiti & 2821.29 & 1669 & 157 & 152 & -5 \\
\hline Rwanda & 2819.85 & 1458 & 158 & 157 & -1 \\
\hline Comoros & 2764.79 & 1456 & 159 & 158 & -1 \\
\hline Madagascar & 2511.24 & 1328 & 160 & 160 & 0 \\
\hline Mozambique & 2354.84 & 1123 & 161 & 162 & 1 \\
\hline Eritrea & 2145.21 & 1130 & 162 & 161 & -1 \\
\hline Guinea & 2126.13 & 1096 & 163 & 163 & 0 \\
\hline Niger & 2073.41 & 908 & 164 & 164 & 0 \\
\hline Malawi & 1615.30 & 747 & 165 & 166 & 1 \\
\hline Burundi & 1583.05 & 758 & 166 & 165 & -1 \\
\hline Democratic Republic of the Congo & 1351.41 & 680 & 167 & 167 & 0 \\
\hline Central African Republic & 1094.73 & 581 & 168 & 168 & 0 \\
\hline
\end{tabular}

Table 7: Values and rankings for the GNI per capita and per adult. 


\begin{tabular}{|c|c|c|c|c|c|c|c|c|}
\hline Country & $\mathrm{HI}$ & EI & YI & DAHDI & HDI & $\mathrm{R}_{\mathrm{DAHDI}}$ & $\mathrm{R}_{\mathrm{HDI}}$ & Diff. R. \\
\hline Australia & 0.858 & 0.917 & 0.960 & 0.910 & 0.935 & 1 & 2 & 1 \\
\hline Israel & 0.961 & 0.812 & 0.945 & 0.904 & 0.894 & 2 & 15 & 13 \\
\hline Norway & 0.831 & 0.878 & 0.998 & 0.900 & 0.944 & 3 & 1 & -2 \\
\hline New Zealand & 0.858 & 0.893 & 0.940 & 0.896 & 0.913 & 4 & 10 & 6 \\
\hline United States of America & 0.818 & 0.894 & 0.981 & 0.895 & 0.915 & 5 & 8 & 3 \\
\hline Switzerland & 0.819 & 0.891 & 0.982 & 0.895 & 0.930 & 6 & 3 & -3 \\
\hline United Kingdom & 0.811 & 0.907 & 0.952 & 0.888 & 0.907 & 7 & 12 & 5 \\
\hline Ireland & 0.875 & 0.823 & 0.958 & 0.884 & 0.916 & 8 & 6 & -2 \\
\hline Denmark & 0.784 & 0.913 & 0.962 & 0.883 & 0.923 & 9 & 4 & -5 \\
\hline Canada & 0.808 & 0.887 & 0.957 & 0.882 & 0.913 & 10 & 10 & 0 \\
\hline Sweden & 0.811 & 0.857 & 0.965 & 0.875 & 0.907 & 11 & 12 & 1 \\
\hline Germany & 0.735 & 0.951 & 0.957 & 0.874 & 0.916 & 12 & 6 & -6 \\
\hline Netherlands & 0.803 & 0.858 & 0.965 & 0.873 & 0.922 & 13 & 5 & -8 \\
\hline Republic of Korea & 0.823 & 0.862 & 0.936 & 0.872 & 0.898 & 14 & 14 & 0 \\
\hline Iceland & 0.878 & 0.787 & 0.947 & 0.868 & 0.899 & 15 & 13 & -2 \\
\hline Belgium & 0.796 & 0.842 & 0.956 & 0.862 & 0.890 & 16 & 18 & 2 \\
\hline Luxembourg & 0.828 & 0.783 & 0.988 & 0.862 & 0.892 & 17 & 16 & -1 \\
\hline France & 0.829 & 0.794 & 0.951 & 0.855 & 0.888 & 18 & 19 & 1 \\
\hline Austria & 0.775 & 0.802 & 0.958 & 0.841 & 0.885 & 19 & 20 & 1 \\
\hline Czech Republic & 0.747 & 0.870 & 0.915 & 0.841 & 0.870 & 20 & 25 & 5 \\
\hline Cyprus & 0.833 & 0.773 & 0.923 & 0.841 & 0.850 & 21 & 30 & 9 \\
\hline Slovenia & 0.752 & 0.859 & 0.917 & 0.840 & 0.880 & 22 & 22 & 0 \\
\hline Finland & 0.781 & 0.793 & 0.950 & 0.838 & 0.883 & 23 & 21 & -2 \\
\hline Estonia & 0.730 & 0.883 & 0.911 & 0.838 & 0.861 & 24 & 27 & 3 \\
\hline Slovakia & 0.742 & 0.856 & 0.913 & 0.834 & 0.844 & 25 & 31 & 6 \\
\hline Japan & 0.756 & 0.812 & 0.942 & 0.833 & 0.891 & 26 & 17 & -9 \\
\hline Chile & 0.890 & 0.718 & 0.903 & 0.833 & 0.832 & 27 & 37 & 10 \\
\hline Poland & 0.747 & 0.835 & 0.903 & 0.826 & 0.843 & 28 & 32 & 4 \\
\hline
\end{tabular}




\begin{tabular}{|c|c|c|c|c|c|c|c|c|}
\hline Country & $\mathrm{HI}$ & EI & YI & DAHDI & HDI & $\mathrm{R}_{\mathrm{DAHDI}}$ & $\mathrm{R}_{\mathrm{HDI}}$ & Diff. R. \\
\hline Lithuania & 0.673 & 0.917 & 0.908 & 0.825 & 0.839 & 29 & 33 & 4 \\
\hline Argentina & 0.856 & 0.711 & 0.912 & 0.822 & 0.836 & 30 & 35 & 5 \\
\hline Saudi Arabia & 0.917 & 0.608 & 0.993 & 0.821 & 0.837 & 31 & 34 & 3 \\
\hline Brunei Darussalam & 0.918 & 0.603 & 1.000 & 0.821 & 0.856 & 32 & 28 & -4 \\
\hline United Arab Emirates & 0.926 & 0.596 & 0.994 & 0.818 & 0.835 & 33 & 36 & 3 \\
\hline Kazakhstan & 0.785 & 0.763 & 0.907 & 0.816 & 0.788 & 34 & 50 & 16 \\
\hline Qatar & 0.894 & 0.601 & 1.000 & 0.813 & 0.850 & 35 & 30 & -5 \\
\hline Spain & 0.807 & 0.713 & 0.932 & 0.812 & 0.876 & 36 & 23 & -13 \\
\hline Italy & 0.770 & 0.741 & 0.933 & 0.810 & 0.873 & 37 & 24 & -13 \\
\hline Greece & 0.754 & 0.773 & 0.907 & 0.809 & 0.865 & 38 & 26 & -12 \\
\hline Azerbaijan & 0.828 & 0.721 & 0.883 & 0.808 & 0.751 & 39 & 70 & 31 \\
\hline Russian Federation & 0.677 & 0.861 & 0.901 & 0.807 & 0.798 & 40 & 44 & 4 \\
\hline Croatia & 0.725 & 0.812 & 0.887 & 0.805 & 0.818 & 41 & 41 & 0 \\
\hline Bahamas & 0.869 & 0.661 & 0.907 & 0.805 & 0.790 & 42 & 49 & 7 \\
\hline Bahrain & 0.880 & 0.615 & 0.954 & 0.803 & 0.824 & 43 & 39 & -4 \\
\hline Belarus & 0.683 & 0.864 & 0.874 & 0.802 & 0.798 & 44 & 44 & 0 \\
\hline Malaysia & 0.880 & 0.634 & 0.920 & 0.801 & 0.779 & 45 & 55 & 10 \\
\hline Turkey & 0.881 & 0.643 & 0.898 & 0.798 & 0.761 & 46 & 65 & 19 \\
\hline Jordan & 0.957 & 0.604 & 0.870 & 0.795 & 0.748 & 47 & 72 & 25 \\
\hline Latvia & 0.684 & 0.818 & 0.899 & 0.795 & 0.819 & 48 & 40 & -8 \\
\hline Sri Lanka & 0.836 & 0.714 & 0.840 & 0.794 & 0.757 & 49 & 66 & 17 \\
\hline Oman & 0.981 & 0.530 & 0.961 & 0.793 & 0.793 & 50 & 47 & -3 \\
\hline Venezuela (Bolivarian Republic of) & 0.891 & 0.625 & 0.889 & 0.791 & 0.762 & 51 & 64 & 13 \\
\hline Cuba & 0.798 & 0.771 & 0.804 & 0.791 & 0.769 & 52 & 60 & 8 \\
\hline Panama & 0.937 & 0.587 & 0.899 & 0.790 & 0.780 & 53 & 54 & 1 \\
\hline Montenegro & 0.723 & 0.788 & 0.862 & 0.789 & 0.802 & 54 & 43 & -11 \\
\hline Albania & 0.845 & 0.687 & 0.835 & 0.785 & 0.733 & 55 & 78 & 23 \\
\hline Romania & 0.715 & 0.769 & 0.881 & 0.785 & 0.793 & 56 & 47 & -9 \\
\hline Costa Rica & 0.928 & 0.590 & 0.866 & 0.780 & 0.766 & 57 & 62 & 5 \\
\hline
\end{tabular}




\begin{tabular}{|c|c|c|c|c|c|c|c|c|}
\hline Country & $\mathrm{HI}$ & EI & YI & DAHDI & HDI & $\mathrm{R}_{\mathrm{DAHDI}}$ & $\mathrm{R}_{\mathrm{HDI}}$ & Diff. R. \\
\hline Uzbekistan & 0.832 & 0.719 & 0.791 & 0.779 & 0.675 & 58 & 104 & 46 \\
\hline Barbados & 0.769 & 0.717 & 0.853 & 0.778 & 0.785 & 59 & 51 & -8 \\
\hline Georgia & 0.732 & 0.799 & 0.803 & 0.777 & 0.754 & 60 & 69 & 9 \\
\hline Armenia & 0.779 & 0.735 & 0.816 & 0.776 & 0.733 & 61 & 78 & 17 \\
\hline Tonga & 0.916 & 0.637 & 0.799 & 0.776 & 0.717 & 62 & 91 & 29 \\
\hline Trinidad and Tobago & 0.743 & 0.682 & 0.919 & 0.775 & 0.772 & 63 & 58 & -5 \\
\hline Bulgaria & 0.683 & 0.779 & 0.867 & 0.773 & 0.782 & 64 & 53 & -11 \\
\hline Mexico & 0.922 & 0.556 & 0.889 & 0.769 & 0.756 & 65 & 67 & 2 \\
\hline Antigua and Barbuda & 0.864 & 0.584 & 0.903 & 0.769 & 0.783 & 66 & 52 & -14 \\
\hline Iran (Islamic Republic of) & 0.891 & 0.579 & 0.879 & 0.768 & 0.766 & 67 & 62 & -5 \\
\hline Mongolia & 0.815 & 0.652 & 0.851 & 0.768 & 0.727 & 68 & 83 & 15 \\
\hline Uruguay & 0.819 & 0.614 & 0.895 & 0.766 & 0.793 & 69 & 47 & -22 \\
\hline Serbia & 0.695 & 0.760 & 0.846 & 0.765 & 0.771 & 70 & 59 & -11 \\
\hline Kyrgyzstan & 0.860 & 0.696 & 0.745 & 0.764 & 0.655 & 71 & 110 & 39 \\
\hline Samoa & 0.917 & 0.604 & 0.800 & 0.762 & 0.702 & 72 & 96 & 24 \\
\hline Peru & 0.905 & 0.572 & 0.855 & 0.762 & 0.734 & 73 & 76 & 3 \\
\hline Algeria & 0.936 & 0.542 & 0.870 & 0.761 & 0.736 & 74 & 75 & 1 \\
\hline Ukraine & 0.668 & 0.812 & 0.811 & 0.761 & 0.747 & 75 & 74 & -1 \\
\hline Kuwait & 0.892 & 0.492 & 1.000 & 0.760 & 0.816 & 76 & 42 & -34 \\
\hline Portugal & 0.783 & 0.612 & 0.913 & 0.759 & 0.830 & 77 & 38 & -39 \\
\hline Brazil & 0.859 & 0.578 & 0.878 & 0.758 & 0.755 & 78 & 68 & -10 \\
\hline Belize & 0.894 & 0.582 & 0.835 & 0.757 & 0.715 & 79 & 92 & 13 \\
\hline Jamaica & 0.936 & 0.564 & 0.822 & 0.757 & 0.719 & 80 & 90 & 10 \\
\hline Turkmenistan & 0.803 & 0.622 & 0.868 & 0.757 & 0.688 & 81 & 100 & 19 \\
\hline Ecuador & 0.930 & 0.544 & 0.853 & 0.756 & 0.732 & 82 & 80 & -2 \\
\hline Tajikistan & 0.911 & 0.645 & 0.733 & 0.755 & 0.624 & 83 & 119 & 36 \\
\hline Seychelles & 0.791 & 0.594 & 0.911 & 0.754 & 0.772 & 84 & 58 & -26 \\
\hline Mauritius & 0.805 & 0.599 & 0.886 & 0.753 & 0.777 & 85 & 56 & -29 \\
\hline Republic of Moldova & 0.723 & 0.755 & 0.775 & 0.751 & 0.693 & 86 & 98 & 12 \\
\hline
\end{tabular}




\begin{tabular}{|c|c|c|c|c|c|c|c|c|}
\hline Country & HI & EI & YI & DAHDI & HDI & $\mathrm{R}_{\mathrm{DAHDI}}$ & $\mathrm{R}_{\mathrm{HDI}}$ & Diff. R. \\
\hline Libya & 0.871 & 0.548 & 0.880 & 0.749 & 0.724 & 87 & 86 & -1 \\
\hline Fiji & 0.815 & 0.623 & 0.821 & 0.747 & 0.727 & 88 & 83 & -5 \\
\hline Former Yugoslav rep. of Macedonia & 0.754 & 0.651 & 0.847 & 0.746 & 0.747 & 89 & 74 & -15 \\
\hline Grenada & 0.812 & 0.593 & 0.850 & 0.742 & 0.750 & 90 & 71 & -19 \\
\hline Colombia & 0.876 & 0.533 & 0.859 & 0.738 & 0.720 & 91 & 88 & -3 \\
\hline Dominican Republic & 0.898 & 0.518 & 0.862 & 0.738 & 0.715 & 92 & 92 & 0 \\
\hline Botswana & 0.843 & 0.528 & 0.900 & 0.738 & 0.698 & 93 & 97 & 4 \\
\hline Bolivia (Plurinational State of) & 0.920 & 0.538 & 0.806 & 0.736 & 0.662 & 94 & 109 & 15 \\
\hline Lebanon & 0.860 & 0.523 & 0.887 & 0.736 & 0.769 & 95 & 60 & -35 \\
\hline Saint Lucia & 0.819 & 0.580 & 0.835 & 0.735 & 0.729 & 96 & 81 & -15 \\
\hline South Africa & 0.754 & 0.601 & 0.865 & 0.732 & 0.666 & 97 & 107 & 10 \\
\hline Philippines & 0.860 & 0.528 & 0.836 & 0.724 & 0.668 & 98 & 105 & 7 \\
\hline Suriname & 0.840 & 0.508 & 0.884 & 0.722 & 0.714 & 99 & 94 & -5 \\
\hline Micronesia (Federated States of) & 0.867 & 0.571 & 0.759 & 0.722 & 0.640 & 100 & 113 & 13 \\
\hline Gabon & 0.908 & 0.448 & 0.914 & 0.719 & 0.684 & 101 & 102 & 1 \\
\hline Bosnia and Herzegovina & 0.738 & 0.611 & 0.825 & 0.719 & 0.733 & 102 & 78 & -24 \\
\hline Saint Vincent and the Grenadines & 0.809 & 0.545 & 0.839 & 0.718 & 0.720 & 103 & 88 & -15 \\
\hline Paraguay & 0.886 & 0.508 & 0.821 & 0.717 & 0.679 & 104 & 103 & -1 \\
\hline China & 0.784 & 0.530 & 0.852 & 0.707 & 0.727 & 105 & 83 & -22 \\
\hline Thailand & 0.784 & 0.524 & 0.858 & 0.706 & 0.726 & 106 & 85 & -21 \\
\hline Tunisia & 0.841 & 0.493 & 0.843 & 0.704 & 0.721 & 107 & 87 & -20 \\
\hline Egypt & 0.891 & 0.453 & 0.859 & 0.703 & 0.690 & 108 & 99 & -9 \\
\hline Indonesia & 0.791 & 0.511 & 0.842 & 0.698 & 0.684 & 109 & 102 & -7 \\
\hline Viet Nam & 0.899 & 0.482 & 0.782 & 0.697 & 0.666 & 110 & 107 & -3 \\
\hline El Salvador & 0.888 & 0.462 & 0.821 & 0.696 & 0.666 & 111 & 107 & -4 \\
\hline Guyana & 0.792 & 0.505 & 0.812 & 0.687 & 0.636 & 112 & 114 & 2 \\
\hline Iraq & 0.926 & 0.387 & 0.896 & 0.685 & 0.654 & 113 & 111 & -2 \\
\hline Maldives & 0.944 & 0.370 & 0.857 & 0.669 & 0.706 & 114 & 95 & -19 \\
\hline Vanuatu & 0.935 & 0.425 & 0.749 & 0.668 & 0.594 & 115 & 124 & 9 \\
\hline
\end{tabular}




\begin{tabular}{|c|c|c|c|c|c|c|c|c|}
\hline Country & HI & EI & YI & DAHDI & HDI & $\mathrm{R}_{\mathrm{DAHDI}}$ & $\mathrm{R}_{\mathrm{HDI}}$ & Diff. R. \\
\hline Namibia & 0.868 & 0.395 & 0.858 & 0.665 & 0.628 & 116 & 116 & 0 \\
\hline Ghana & 0.835 & 0.437 & 0.779 & 0.658 & 0.579 & 117 & 129 & 12 \\
\hline Timor-Leste & 0.933 & 0.373 & 0.815 & 0.657 & 0.595 & 118 & 123 & 5 \\
\hline Cabo Verde & 0.908 & 0.385 & 0.808 & 0.656 & 0.646 & 119 & 112 & -7 \\
\hline Guatemala & 0.948 & 0.359 & 0.828 & 0.656 & 0.627 & 120 & 118 & -2 \\
\hline Nicaragua & 0.937 & 0.386 & 0.778 & 0.655 & 0.631 & 121 & 115 & -6 \\
\hline Honduras & 0.976 & 0.366 & 0.776 & 0.652 & 0.606 & 122 & 121 & -1 \\
\hline Congo & 0.877 & 0.384 & 0.822 & 0.652 & 0.591 & 123 & 126 & 3 \\
\hline Sao Tome and Principe & 0.940 & 0.383 & 0.764 & 0.650 & 0.555 & 124 & 132 & 8 \\
\hline Swaziland & 0.778 & 0.410 & 0.809 & 0.637 & 0.531 & 125 & 139 & 14 \\
\hline Kenya & 0.869 & 0.387 & 0.755 & 0.633 & 0.548 & 126 & 134 & 8 \\
\hline India & 0.830 & 0.384 & 0.795 & 0.633 & 0.609 & 127 & 120 & -7 \\
\hline Syrian Arab Republic & 0.820 & 0.409 & 0.740 & 0.629 & 0.594 & 128 & 124 & -4 \\
\hline Zambia & 0.888 & 0.344 & 0.791 & 0.623 & 0.586 & 129 & 128 & -1 \\
\hline Cameroon & 0.813 & 0.387 & 0.759 & 0.621 & 0.512 & 130 & 142 & 12 \\
\hline Morocco & 0.881 & 0.333 & 0.812 & 0.620 & 0.628 & 131 & 116 & -15 \\
\hline Lao Peoples Democratic Republic & 0.868 & 0.346 & 0.791 & 0.619 & 0.575 & 132 & 130 & -2 \\
\hline Zimbabwe & 0.836 & 0.400 & 0.703 & 0.617 & 0.509 & 133 & 144 & 11 \\
\hline Equatorial Guinea & 0.819 & 0.305 & 0.933 & 0.615 & 0.587 & 134 & 127 & -7 \\
\hline Bangladesh & 0.885 & 0.345 & 0.749 & 0.612 & 0.570 & 135 & 131 & -4 \\
\hline Madagascar & 0.892 & 0.349 & 0.690 & 0.599 & 0.510 & 136 & 143 & 7 \\
\hline Nigeria & 0.785 & 0.331 & 0.816 & 0.596 & 0.514 & 137 & 141 & 4 \\
\hline Uganda & 0.906 & 0.320 & 0.722 & 0.594 & 0.483 & 138 & 150 & 12 \\
\hline Comoros & 0.874 & 0.341 & 0.698 & 0.593 & 0.503 & 139 & 147 & 8 \\
\hline Angola & 0.803 & 0.301 & 0.839 & 0.588 & 0.532 & 140 & 138 & -2 \\
\hline Pakistan & 0.888 & 0.284 & 0.792 & 0.584 & 0.538 & 141 & 136 & -5 \\
\hline Bhutan & 0.860 & 0.278 & 0.817 & 0.580 & 0.605 & 142 & 122 & -20 \\
\hline United Republic of Tanzania & 0.860 & 0.299 & 0.749 & 0.578 & 0.521 & 143 & 140 & -3 \\
\hline Cambodia & 0.865 & 0.298 & 0.744 & 0.577 & 0.555 & 144 & 132 & -12 \\
\hline
\end{tabular}




\begin{tabular}{|c|c|c|c|c|c|c|c|c|}
\hline Country & HI & EI & YI & DAHDI & HDI & $\mathrm{R}_{\mathrm{DAHDI}}$ & $\mathrm{R}_{\text {HDI }}$ & Diff. R. \\
\hline Benin & 0.867 & 0.303 & 0.720 & 0.574 & 0.480 & 145 & 152 & 7 \\
\hline Democratic Republic of the Congo & 0.876 & 0.337 & 0.635 & 0.572 & 0.433 & 146 & 159 & 13 \\
\hline Nepal & 0.871 & 0.292 & 0.725 & 0.569 & 0.548 & 147 & 134 & -13 \\
\hline Rwanda & 0.907 & 0.278 & 0.700 & 0.561 & 0.483 & 148 & 150 & 2 \\
\hline Afghanistan & 0.867 & 0.274 & 0.724 & 0.556 & 0.465 & 149 & 156 & 7 \\
\hline Mauritania & 0.879 & 0.251 & 0.774 & 0.555 & 0.506 & 150 & 145 & -5 \\
\hline Myanmar & 0.795 & 0.272 & 0.776 & 0.552 & 0.536 & 151 & 137 & -14 \\
\hline Papua New Guinea & 0.804 & 0.284 & 0.734 & 0.551 & 0.505 & 152 & 146 & -6 \\
\hline Malawi & 0.822 & 0.310 & 0.651 & 0.549 & 0.445 & 153 & 157 & 4 \\
\hline Djibouti & 0.849 & 0.252 & 0.756 & 0.545 & 0.470 & 154 & 154 & 0 \\
\hline Haiti & 0.850 & 0.272 & 0.700 & 0.545 & 0.483 & 155 & 150 & -5 \\
\hline Yemen & 0.897 & 0.230 & 0.777 & 0.543 & 0.498 & 156 & 148 & -8 \\
\hline Sudan & 0.892 & 0.221 & 0.783 & 0.536 & 0.479 & 157 & 153 & -4 \\
\hline Senegal & 0.919 & 0.212 & 0.737 & 0.523 & 0.466 & 158 & 155 & -3 \\
\hline Burundi & 0.865 & 0.254 & 0.649 & 0.522 & 0.400 & 159 & 164 & 5 \\
\hline Eritrea & 0.863 & 0.235 & 0.676 & 0.516 & 0.391 & 160 & 166 & 6 \\
\hline Mozambique & 0.829 & 0.240 & 0.684 & 0.514 & 0.416 & 161 & 161 & 0 \\
\hline Ethiopia & 0.915 & 0.211 & 0.702 & 0.514 & 0.442 & 162 & 158 & -4 \\
\hline Guinea & 0.843 & 0.219 & 0.675 & 0.500 & 0.411 & 163 & 162 & -1 \\
\hline Mali & 0.871 & 0.195 & 0.718 & 0.496 & 0.419 & 164 & 160 & -4 \\
\hline Central African Republic & 0.766 & 0.239 & 0.617 & 0.484 & 0.350 & 165 & 167 & 2 \\
\hline Chad & 0.803 & 0.180 & 0.737 & 0.474 & 0.392 & 166 & 165 & -1 \\
\hline Burkina Faso & 0.869 & 0.165 & 0.714 & 0.468 & 0.402 & 167 & 163 & -4 \\
\hline Niger & 0.919 & 0.141 & 0.673 & 0.443 & 0.348 & 168 & 168 & 0 \\
\hline
\end{tabular}

Table 8: Values, component, and ranking of the DAHDI. 
Development Countries

Very high Albania, Argentina, Australia, Austria, Azerbaijan, Bahamas, Bahrain, Belarus, Belgium, Brunei Darussalam, Canada, Chile, Croatia, Cuba, Cyprus, Czech Republic, Denmark, Estonia, Finland, France, Germany, Greece, Iceland, Ireland, Israel, Italy, Japan, Jordan, Kazakhstan, Latvia, Lithuania, Luxembourg, Malaysia, Montenegro, Netherlands, New Zealand, Norway, Oman, Panama, Poland, Qatar, Republic of Korea, Romania, Russian Federation, Saudi Arabia, Slovakia, Slovenia, Spain, Sri Lanka, Sweden, Switzerland, Turkey, United Arab Emirates, United Kingdom, United States of America, Venezuela (Bolivarian Republic of)

High Algeria, Antigua and Barbuda, Armenia, Barbados, Belize, Bolivia (Plurinational State of), Bosnia and Herzegovina, Botswana, Brazil, Bulgaria, China, Colombia, Costa Rica, Dominican Republic, Ecuador, Egypt, El Salvador, Fiji, Gabon, Georgia, Grenada, Guyana, Indonesia, Iran (Islamic Republic of), Iraq, Jamaica, Kuwait, Kyrgyzstan, Lebanon, Libya, Mauritius, Mexico, Micronesia (Federated States of), Mongolia, Paraguay, Peru, Philippines, Portugal, Republic of Moldova, Saint Lucia, Saint Vincent and the Grenadines, Samoa, Serbia, Seychelles, South Africa, Suriname, Tajikistan, Thailand, The former Yugoslav republic of Macedonia, Tonga, Trinidad and Tobago, Tunisia, Turkmenistan, Ukraine, Uruguay, Uzbekistan, Viet Nam

Medium Bangladesh, Cabo Verde, Cameroon, Congo, Equatorial Guinea, Ghana, Guatemala, Honduras, India, Kenya, Lao Peoples Democratic Republic, Maldives, Morocco, Namibia, Nicaragua, Sao Tome and Principe, Swaziland, Syrian Arab Republic, Timor-Leste, Vanuatu, Zambia, Zimbabwe

Low Afghanistan, Angola, Benin, Bhutan, Burkina Faso, Burundi, Cambodia, Central African Republic, Chad, Comoros, Democratic Republic of the Congo, Djibouti, Eritrea, Ethiopia, Guinea, Haiti, Madagascar, Malawi, Mali, Mauritania, Mozambique, Myanmar, Nepal, Niger, Nigeria, Pakistan, Papua New Guinea, Rwanda, Senegal, Sudan, Uganda, United Republic of Tanzania, Yemen

Table 9: Distribution of countries in four groups according to the DAHDI. 
Very high Argentina, Australia, Austria, Bahrain, Belgium, Brunei Darussalam, Canada, Chile, Croatia, Cyprus, Czech Republic, Denmark, Estonia, Finland, France, Germany, Greece, Iceland, Ireland, Israel, Italy, Japan, Kuwait, Latvia, Lithuania, Luxembourg, Netherlands, New Zealand, Norway, Poland, Portugal, Qatar, Republic of Korea, Saudi Arabia, Slovakia, Slovenia, Spain, Sweden, Switzerland, United Arab Emirates, United Kingdom, United States of America

High Albania, Algeria, Antigua and Barbuda, Armenia, Azerbaijan, Bahamas, Barbados, Belarus, Belize, Bolivia (Plurinational State of), Bosnia and Herzegovina, Botswana, Brazil, Bulgaria, China, Colombia, Costa Rica, Cuba, Dominican Republic, Ecuador, Egypt, El Salvador, Fiji, Gabon, Georgia, Grenada, Indonesia, Iran (Islamic Republic of), Iraq, Jamaica, Jordan, Kazakhstan, Kyrgyzstan, Lebanon, Libya, Malaysia, Maldives, Mauritius, Mexico, Mongolia, Montenegro, Oman, Panama, Paraguay, Peru, Philippines, Republic of Moldova, Romania, Russian Federation, Saint Lucia, Saint Vincent and the Grenadines, Samoa, Serbia, Seychelles, South Africa, Sri Lanka, Suriname, Thailand, The former Yugoslav republic of Macedonia, Tonga, Trinidad and Tobago, Tunisia, Turkey, Turkmenistan, Ukraine, Uruguay, Uzbekistan, Venezuela (Bolivarian Republic of), Viet Nam

Medium Bangladesh, Bhutan, Cabo Verde, Congo, Equatorial Guinea, Ghana, Guatemala, Guyana, Honduras, India, Lao Peoples Democratic Republic, Micronesia (Federated States of), Morocco, Namibia, Nicaragua, Syrian Arab Republic, Tajikistan, TimorLeste, Vanuatu, Zambia

Low Afghanistan, Angola, Benin, Burkina Faso, Burundi, Cambodia, Cameroon, Central African Republic, Chad, Comoros, Democratic Republic of the Congo, Djibouti, Eritrea, Ethiopia, Guinea, Haiti, Kenya, Madagascar, Malawi, Mali, Mauritania, Mozambique, Myanmar, Nepal, Niger, Nigeria, Pakistan, Papua New Guinea, Rwanda, Sao Tome and Principe, Senegal, Sudan, Swaziland, Uganda, United Republic of Tanzania, Yemen, Zimbabwe

Table 10: Distribution of countries in four groups according to the HDI. 